Folia Hort. 29/2 (2017): 199-220

DOI: 10.1515/fhort-2017-0019
Published by the Polish Society

for Horticultural Science since 1989

\title{
Environmental and nutritional requirements for tea cultivation
}

\author{
Roghieh Hajiboland \\ Plant Science Department \\ University of Tabriz \\ 51666-14779 Tabriz, Iran
}

\begin{abstract}
Tea (Camellia sinensis) is an important beverage crop cultivated in the tropics and subtropics under acid soil conditions. Increased awareness of the health-promoting properties of the tea beverage has led to an increase in its level of consumption over the last decades. Tea production contributes significantly to the economy of several tea-cultivating countries in Asia and Africa. Environmental constrains, particularly water deficiency due to inadequate and/or poorly distributed rainfall, seriously limit tea production in the majority of tea-producing countries. It is also predicted that global climate change will have a considerable adverse impact on tea production in the near future. Application of fertilizers for higher production and increased quality and quantity of tea is a common agricultural practice, but due to its environmental consequences, such as groundwater pollution, the rate of fertilizer application needs to be reconsidered. Cultivation of tea under humid conditions renders it highly susceptible to pathogens and pest attacks. Application of pesticides and fungicides adversely affects the quality of tea and increases health risks of the tea beverage. Organic cultivation as an agricultural practice without using synthetic fertilizers and other chemical additives such as pesticides and fungicides is a sustainable and eco-friendly approach to producing healthy tea. A growing number of tea-producing countries are joining organic tea cultivation programmes in order to improve the quality and to maintain the health benefits of the tea produced.
\end{abstract}

Key words: aluminium, global climate change, nitrogen fertilizers, organic culture, phosphorus fertilizers, soil $\mathrm{pH}$, water deficiency

\section{Abbreviations:}

$\mathrm{C}_{\mathrm{a}}$ - atmospheric $\mathrm{CO}_{2}$ concentration, $\mathrm{T}_{\mathrm{a}}$ - atmospheric temperature, ESTs - estimated sequence tags, $\mathrm{N}_{\mathrm{sh}}$ - harvestable shoot density, $\mathrm{W}_{\mathrm{sh}}$ - harvestable shoot weight, $\mathrm{C}_{\mathrm{i}}$ - intracellular $\mathrm{CO}_{2}$ concentration, $\mathrm{T}_{1}-$ leaf temperature, $\mathrm{P}_{\max }-$ maximum photosynthetic rate, $\mathrm{T}_{\mathrm{m}}$ - maximum temperature, $\mathrm{P}_{\mathrm{n}}-$ net photosynthetic rate, $\mathrm{T}_{\mathrm{o}}$ - optimum temperature, PAR - photosynthetic active radiation, ROS - reactive oxygen species, $\mathrm{SER}$ - shoot extension rate, SRC - shoot replacement cycle, $\mathrm{T}_{\mathrm{s}}$ - soil temperature, $\mathrm{SWD}$ - soil water deficit, $\mathrm{g}_{\mathrm{s}}-$ stomatal conductance, $\mathrm{SSH}$ technique - suppression subtractive hybridization technique, $\mathrm{T}_{t}$ - threshold temperature, TE - transpiration efficiency, VPD - vapour pressure deficit, WUE - water use efficiency

\section{INTRODUCTION}

Tea [Camellia sinensis (L.) O. Kuntze] (Theaceae) is the most widely consumed beverage in the world, ranked second after water as the most consumed drink worldwide (Zhen 2002, Ho et al. 2009). Besides being a traditional beverage, tea has a more significant role as a health drink. It is 
produced in 50 countries, with major producers being China, India, Kenya, Sri Lanka, Vietnam, Turkey, Indonesia and Iran (FAO 2014). World production now stands at 5.56 million tons, with plantation coverage of 3.80 million hectares (FAO 2014). Globally, tea continues its steady increase in production, doubling in the past 20 years in 2014.

The tea plant grows as an evergreen bush and attains a height of up to $15 \mathrm{~m}$ in the wild. In cultivation, however, the crop is maintained at 0.6-1.0 $\mathrm{m}$ tall to facilitate harvesting of the leaves (de Costa et al. 2007). Tea has a productive lifespan of over 100 years, but its peak production period is between the 30th and 50th year. Tea bushes can be raised from seed, cuttings or tissue culture. Propagation from seed is rare, while vegetative propagation is common because it is high-yielding, fast and cheap, and leads to the development of uniform stands. Tissue culture, on the other hand, is a rapid method of propagation, but is expensive and therefore appropriate only for breeding purposes (TRFK 2002).

Commercially grown teas are hybrids of two distinct ecotypes: the Assam-type (var. assamica) and the China-type (var. sinensis). The two ecotypes and their hybrids exhibit considerable variation in their ecophysiology. The China-type has small (3-6 cm long), relatively erect, darkgreen leaves with a matt surface, while the Assamtype has larger (15-20 cm long), more horizontally held, light-green leaves with a glossy surface. The Assam-type originated under the shade of humid, tropical forests, while the China-type originated under open-field conditions in the cool, humid tropics. The China-type is known to be more resistant to both cold and hot drought conditions with higher yield quantity and quality. Because of intense interbreeding, commercial cultivars may have characters intermediate between those of the two ecotypes, i.e. 'agrotypes'. This variation in the tea germplasm can be used to develop cultivars that are specifically adapted to different climates (Carr and Stephens 1992, de Costa et al. 2007).

Although tea is native to the humid tropics and subtropics, it has a very wide adaptability and thus can be grown in a wide range of climatic conditions and soils from Mediterranean to warm, humid tropics, from countries such as Russia in the northern latitudes to Argentina and Australia in the southern latitudes. Tea is also grown across a range of altitudes, from sea level up to about $2200 \mathrm{~m}$ above sea level (a.s.l.). The tea plant requires a minimum rainfall of $1200 \mathrm{~mm}^{\text {year }}{ }^{-1}$, but $2500-3000 \mathrm{~mm}$ year ${ }^{-1}$ is considered optimum. The distribution of rainfall is very important in the countries with rain-fed tea production systems such as Kenya, Sri-Lanka and India (Carr 1972).

Tea is grown in soils that differ from one country to another, with the most important feature being the soil $\mathrm{pH}$. The $\mathrm{pH}$ requirement for the growth of tea is in the range of 4.5-5.6. The optimum soil conditions recommended for tea growth include a well-drained, deep and well-aerated soil with more than $2 \%$ organic matter (de Silva 2007). For economic tea production, other characteristics have to be considered, including the slope of the field, graveliness and rockiness of the soil. Soil depth of less than $50 \mathrm{~cm}$, graveliness of more than $50 \%$ and rockiness of $20 \%$ affect the growth of tea adversely. Tea plants growing in shallow and compacted soils are likely to suffer from drought and waterlogging during the rainy months (TRFK 2002).

The harvested leaf yield of tea, i.e. 'made tea', can generally reach 4-5 $\mathrm{t} \mathrm{ha}^{-1}$ year $^{-1}$ under favourable climatic and soil conditions with proper management. There have been occasions when yields of up to $6.5 \mathrm{t} \mathrm{ha}^{-1}$ year ${ }^{-1}$ were reported. Even at these upper limits, tea yield is much lower than the yield of other leaf crops $\left(\sim 10-20 \mathrm{t} \mathrm{ha}^{-1}\right.$ year $\left.{ }^{1}\right)$. In the absence of soil constraints and under proper management, tea yield at lower elevations is higher than that obtained from tea stands at higher elevations (Carr and Stephens 1992, TRFK 2002).

\section{ECONOMIC IMPORTANCE OF TEA}

Millions of farmers and workers around the world depend on tea for their living. In several African and Asian countries, tea is an economically important crop contributing significantly to foreign exchange earnings and rural development. The tea industry also provides employment and a direct means of livelihood for many other people. Tea is produced both on large plantations and small plots of land; however, there are limitations on land availability in both commercial and smallholder sectors. Further increases in production will, therefore, arise largely from the intensification of production from existing tea stands, or from further planting in the more marginal areas where climate or soil conditions may be the limiting factors (FAO 2015).

The price of tea is determined by its quality, i.e. its chemical composition. The chemical composition of tea, in turn, is influenced by environmental 
conditions, production practices and the genetic makeup of the clones.

\section{PROCESSING, PHYTOCHEMISTRY AND HEALTH EFFECTS OF TEA}

Tea is consumed mainly as either a 'black' (fermented), 'green' (non-fermented) or 'oolong' (semi-fermented) tea beverage. The type of tea produced is different among different tea-producing countries. Sri Lanka is mainly producing orthodox black tea. South-East Asia, i.e. India and Sri Lanka, and eastern, and southern Africa, i.e. Kenya, Malawi, Tanzania, Uganda and Mozambique, are the major producers of black tea, while China and Japan produce mainly green tea (FAO 2015).

Tea has about 2000 components in its chemical composition. Different types of tea differ depending on the phytochemical composition. The same type of tea can have a varied chemical composition depending on various factors including soil, climate, altitude, degree of oxidation and storage conditions. The harvested part of the tea plant affects the quality of tea because leaf age is an important factor determining its chemical composition in terms of the polyphenol (particularly catechin) content (Ho et al. 2009, Yashin et al. 2015).

The amount and ratio of green tea catechins determine the quality of both green and black tea. The upper, younger, shoots have higher levels of catechins; thus, for high quality teas two or three leaves and a bud are harvested (de Costa et al. 2007). Maceration of tea shoots initiates oxidation of catechins by polyphenol oxidase (PPO), leading to the formation of theaflavins (TFs) and thearubigins (TRs). Black tea contains the lowest levels of catechins due to the oxidation during processing. The briskness and brightness of the tea liquor from fermented black tea are contributed by theaflavins. Thearubigins, the orange brown compounds, are responsible for the colour and taste of tea. Thearubigins contribute approximately $35 \%$ of total colour, and also play a significant role in the brown colour of tea, as well as in the strength and mouth feel of the tea liquor (Kumar et al. 2011, Karori et al. 2014).

Green tea leaves contain a large group of compounds, including polysaccharides, volatile oils, vitamins, minerals, purines, alkaloids and polyphenols, the most significant of them being the polyphenols, particularly flavan-3-ols (catechins). Catechins make up $18-30 \%$ of the dry weight in green tea. The five major variants of catechins are: trihydroxy-flavan-3-ol gallic acid ester (epigallocatechin gallate, EGCG), trihydroxyflavan-3-ol (epigallocatechin, EGC), dihydroxyflavan-3-ol gallic acid ester (epicatechin gallate, ECG), dihydroxy-flavan-3-ol (epicatechin, EC) and gallocatechin (GC). Gallic acid (GA) also occurs at low levels. Recently, o-methylated EGCG (epigallocatechin-3-(0-3-methy)) and epigallocatechin-3-o-(4-o-methyl) gallate have also been reported in some green tea cultivars (Harbowy and Balentine 1997, Anesini et al. 2008).

The popularity of tea leaf extracts is also ascribed to its medicinal benefits, particularly its antioxidant activity (Dufresne and Farnworth 2001). Some epidemiological studies have associated the consumption of tea with either reduced occurrence or absence of certain illnesses. All variants of catechins contribute to the antioxidant activities ascribed to tea (Patel 2005, Anesini et al. 2008). EGCG is the most studied, and is thought to be a more potent antioxidant than ascorbate. In addition, tea has antimutagenic (Ioannides and Yoxall 2003) and anticancer properties; the latter has been shown by the inhibition of tumour cells (Mukhtar and Ahmad 1999, Morré et al. 2003) and is recommended for treatment of periodontal disease and decubitus ulcers. EGCG is the principal compound of tea with a healing effect, but some studies suggest a synergistic advantage when used along with EC, EGC and/or ECG (Morré et al. 2003). Tea also contains theanine, a rare amino acid that has been shown to induce relaxation, lower blood pressure and decrease anxiety (Dufresne and Farnworth 2001). It has been shown that $1-2$ cups of tea contain about $200 \mathrm{mg}$ of vitamin C, equivalent to three glasses of orange juice (du Toit et al. 2001).

Tea seed contains $40-50 \%$ oil with a quality comparable to olive oil, which is used as cooking oil, particularly in China's southern provinces (Ruter 2002). Other benefits of tea include antibacterial, antiseptic and detoxifying properties which help reduce digestive complaints and guard against tooth decay due to rich fluoride content in green tea (Kavanagh and Renehan 1997, Hara 2001). Green tea polyphenols also act as neuroprotective agents (Weinreb et al. 2004).

There are also possible health risks associated with tea consumption, including anaemia caused by reduced ability to utilize dietary iron as a result of the antioxidant action of tea polyphenols (du Toit et al. 2001). In addition, tea is an aluminium (Al) accumulator species, and $\mathrm{Al}$ is found in an amount of 2-17 mg L-1 in tea infusion (Karak and Bhagat 2010). As a neurotoxic metal, Al accumulates 
in Alzheimer's disease-susceptible neuronal foci. Very small amounts of $\mathrm{Al}$ are needed to produce neurotoxicity, and experimental evidence has demonstrated that chronic Al intoxication reproduces neuropathological hallmarks of Alzheimer's disease (Tomljenovic 2011).

\section{TEA YIELD AND PRODUCTIVITY FROM THE PHYSIOLOGICAL POINT OF VIEW}

Tea yield is determined by the area harvested and the weight of the tea leaves plucked. Two or three leaves and a bud are plucked, and the height of the canopy is maintained at an optimal level for plucking, the so-called 'plucking table', that is much lower than the level to which tea bushes would grow naturally. Tea bushes are plucked in 7- to 10-day cycles.

Because of plucking and a low photosynthetic capacity of young tea leaves, young buds and shoots are dependent on a layer of mature leaves under the plucking table, i.e. 'maintenance foliage', for their supply of assimilates. As the tea leaf matures, the net photosynthetic rate $\left(\mathrm{P}_{\mathrm{n}}\right)$ gradually increases, reaching a maximum $\left(\mathrm{P}_{\max }\right)$ when shoots are ready for harvesting (Sanderson and Sivapalan 1966a). Leaves of different ages synthesize different types of compounds from photosynthetically assimilated carbon. In immature leaves, a relatively large proportion of assimilated carbon is incorporated into flavanols (catechins), amino acids, organic acids, etc. In mature leaves, in contrast, most of the assimilated carbon is incorporated into easily translocatable substances, such as sugars (Sanderson and Sivapalan 1966a). In intact bushes, carbon assimilated by mature leaves supports the flush, i.e. the harvested immature shoots, and roots (Sanderson and Sivapalan 1966b).

Tea exhibits the $\mathrm{C}_{3}$ mechanism of photosynthesis, and under normal ambient atmospheric conditions the rate of photorespiration is around $19 \%$ of net photosynthesis (de Costa et al. 2007). The $P_{\max }$ of tea $\left(2-14 \mu \mathrm{mol} \mathrm{m} \mathrm{m}^{-2} \mathrm{~s}^{-1}\right)$ is lower than that of most other tropical plants $\left(20-40 \mu \mathrm{mol} \mathrm{m} \mathrm{m}^{-2} \mathrm{~s}^{-1}\right)$, which is related to a lower efficiency of photosystem II in capturing the excitation energy and to lower rates of linear electron transport, smaller proportion of the energy from electron transport that supports carboxylation of ribulose bis-phosphate (RuBP), low rates of RuBP carboxylation and low amounts and activity of ribulose bis-phosphate carboxylaseoxygenase (Rubisco), and finally a higher resistance imposed by stomata and mesophyll to the diffusion of $\mathrm{CO}_{2}$ towards carboxylation sites (Mohotti et al. 2000). All these factors impose a source-limitation on tea yield (de Costa et al. 2007).

It has been stated that the current rate of $P_{n}$ is not directly linked to leaf yield of tea because leaf yield is controlled mainly by the rates of shoot initiation and extension rather than by the supply of assimilates from current $\mathrm{P}_{\mathrm{n}}$ (Squire and Callander 1981). The rates of shoot initiation and extension are primarily controlled by air temperature and humidity, as well as shoot turgor (Squire 1979), whereas $P_{n}$ is primarily controlled by light intensity. Assimilates produced during periods of slow shoot growth are subsequently used during periods of higher growth, thus, over a longer time period, time-integrated tea yield and $\mathrm{P}_{\mathrm{n}}$ are positively correlated (Smith et al. 1993).

Respiration rate also influences growth rates of tea. Mature tea which accumulates biomass at a rate of $17.5 \mathrm{t} \mathrm{ha}^{-1}$ year ${ }^{-1}$ uses $67-85 \%$ of its photoassimilates for respiration (Tanton 1979). These respiratory losses are much greater than those of annual crops, i.e. 30-50\% (Charles-Edwards 1982). Respiratory loss is higher in higher-yielding cultivars than in the lower-yielding ones. Because of the increase in total biomass with time during the period between two successive prunings, 'maintenance respiration', i.e. respiration that is generating metabolic energy for the maintenance of existing biomass, increases throughout the pruning cycle (de Costa et al. 2007). The respiratory costs of tea roots for maintenance and nitrate uptake are $0.324 \mu \mathrm{mol} \mathrm{CO}_{2} \mathrm{~kg}^{-1}$ (root dry matter) $\mathrm{s}^{-1}$ and $0.64 \mathrm{~mol} \mathrm{CO}_{2}(\mathrm{~mol} \mathrm{~N})^{-1}$, respectively. Root respiration rates increase with increasing $\mathrm{N}$ supply, primarily because of the higher respiratory cost for nitrate uptake. Daily 'growth respiration', i.e. respiration that is generating metabolic energy for the synthesis of new biomass, varies from 4.42 to $6.96 \mathrm{~g} \mathrm{CO}_{2} \mathrm{~m}^{-2}$ (land area) $\mathrm{d}^{-1}$ in two cultivars of mature, field-grown tea at a high altitude in Sri Lanka (Anandacoomaraswamy et al. 2002). These rates vary for different years and are positively correlated with the variation in biomass production rates in different years (de Costa et al. 2007).

\section{ENVIRONMENTAL REQUIREMENTS FOR TEA PRODUCTION}

Environmental and climatic conditions determine the rate of shoot expansion and tea yield. Various components of the environment influence the growth and productivity of tea to a different extent. Light, $\mathrm{CO}_{2}$, temperature and water availability 
are the most important factors determining tea productivity.

\section{Effect of light environment}

The net photosynthetic rate in fully expanded mature leaves of tea shows an asymptotic response to increasing light intensity. Reported values for saturating light intensities range from $600-800 \mu \mathrm{mol}$ $\mathrm{m}^{-2} \mathrm{~s}^{-1}$ up to $1200-1500 \mu \mathrm{mol} \mathrm{m}^{-2} \mathrm{~s}^{-1}$ of photosynthetic active radiation (PAR) (Mohotti 2004, Okano et al. 1995). The genotype $\times$ environment interaction, the effect of $\mathrm{N}$ supply, and the stages of the pruning cycle are factors responsible for such variation in the reported saturating PAR. Usually, $\mathrm{P}_{\max }$ declines during the latter part of the pruning cycle in parallel with an increase in dark respiration rate (Mohotti 1998). In a greenhouse experiment, the optimum light intensity for $\mathrm{CO}_{2}$ assimilation was lower for young leaves $\left(250 \mu \mathrm{mol} \mathrm{m} \mathrm{m}^{-2} \mathrm{~s}^{-1}\right)$ than that for old leaves $\left(500 \mu \mathrm{mol} \mathrm{m}^{-2} \mathrm{~s}^{-1}\right)$ (Hajiboland et al. 2011).

\section{Photoinhibition and shade adaptation in tea}

The energy stored in Chl molecules in the excited state is rapidly transferred and thus quenched by the application of electrons in the dark reactions, i.e. photochemical quenching. The excitation energy beyond the capacity of photochemical reactions is quenched by non-photochemical processes, i.e. nonphotochemical quenching, mainly as the conversion of energy to heat, i.e. heat dissipation, mediated by xanthophyll cycle pigments. Photoinhibition occurs when these photoprotection mechanisms cannot efficiently quench excess excitation energy, resulting in damage to photosystems (Hajiboland 2014).

Because the tea plant originated as an understorey plant in tropical rainforests, its photosynthetic apparatus is adapted to function with maximum capacity under shade (de Costa et al. 2007). Parameters such as photosynthetic light capture, electron transport, photochemical and non-photochemical energy quenching and carboxylation have shown that the entire photosynthetic apparatus of the tea plant is shadeadapted (Mohotti and Lawlor 2002). Tea leaf $\mathrm{P}_{\mathrm{n}}$ decreases due to photoinhibition when light intensity increases beyond $1400-1500 \mu \mathrm{mol} \mathrm{m}^{-2} \mathrm{~s}^{-1}$ (Mohotti and Lawlor 2002). Interestingly, abundant application of $\mathrm{N}$ fertilizers, e.g. $375 \mathrm{~kg} \mathrm{~N}^{-1}$ year $^{-1}$, minimizes photoinhibition in tea in the normal range of light intensities, i.e. up to $2000 \mu \mathrm{mol}$ $\mathrm{m}^{-2} \mathrm{~s}^{-1}$ (Smith et al. 1993). Significant photoinhibition in tea has been observed on clear and sunny days, but not on cloudy days (Karunaratne et al. 2003).
The optimum shading level for tea yield is $30-40 \%$ (Gamage et al. 2007).

It has been observed that under shade conditions, higher $\mathrm{P}_{\mathrm{n}}$ and lower photoinhibition in tea leaves is due to an increase in PSII efficiency and photochemical quenching and reduction in stomatal conductance $\left(\mathrm{g}_{\mathrm{s}}\right)$ (Karunaratne et al. 2003). Shade can also influence $\mathrm{P}_{\mathrm{n}}$ indirectly by regulating leaf and canopy temperatures. Shade reduces leaf temperature $\left(\mathrm{T}_{1}\right)$ by $10-12^{\circ} \mathrm{C}$ at midday (Gee et al. 1982). Under warm, tropical conditions, e.g. in Sri Lanka and India, shade reduces $\mathrm{T}_{1}$, which exceeds the optimum for $\mathrm{P}_{\mathrm{n}}$ on sunny days (Sivapalan 1993). However, in certain other parts of the world, for example in the cool highlands of Kenya, where sub-optimal temperatures prevail, shade is not considered necessary (Smith et al. 1993). Shading also has a dual effect in relation to pest and disease control (see below).

The tea plant possesses a large xanthophyll cycle pool, which may have a pivotal role in photoprotection. Violaxanthin, antheraxanthin and zeaxanthin have been detected in tea leaves. Large amounts of xanthophyll pigments are found in deepoxidation state under high-sunlight conditions (Wei et al. 2004). In tea grown under greenhouse conditions it has been observed that photochemical events in young leaves are more protected from excess light than in mature leaves. Moreover, the antioxidant defence system is involved in the protection of leaves against excess excitation energy under intermediate light conditions, while thermal dissipation (non-photochemical quenching) performs this role under higher light conditions (Hajiboland et al. 2011). To provide partial shading at different times of the day, tall trees (10-15 $\mathrm{m})$ and shrubs (3-5 m) are grown among tea bushes in commercial plantations (de Costa et al. 2007).

\section{Photoperiod}

Fluctuations in the yield of tea during the year, i.e. short-term variation within a growing season, and variation between the seasons of the year are welldocumented phenomena in many environments (Barua 1969, Carr 1972, de Costa et al. 2007). The short-term fluctuations are due to successive cohorts of shoots reaching harvestable size at similar times after synchronization at the beginning of the season (Fordham and Palmer-Jones 1977). However, the causes of seasonal variations and the resting state of shoots have been attributed to the photoperiod. Promotion of and release from bud 
rest in tea is mediated by the photoperiod $(\Phi)$ acting as a switch mechanism. The photoperiod influences shoot growth in two ways: by determining when a bud commences and finishes development, and by regulating its subsequent development and extension rate (Barua 1969, Tanton 1982). It is noteworthy that the critical photoperiod is not exactly the same for the two processes: $12.00 \mathrm{~h}$ for the development and extension process and $12.15 \mathrm{~h}$ for the switching process (Matthews and Stephens 1998b). Interestingly, the release from the resting state is not triggered by an absolute $\Phi$. Different models indicate that the plant is able to detect the occurrence of the winter solstice, which implies a response to the rate of change in the photoperiod $(\mathrm{d} \Phi / \mathrm{dt})$. Buds are predisposed to remain or become resting when $\mathrm{d} \Phi / \mathrm{dt}$ is negative, and are released from rest when $\mathrm{d} \Phi / \mathrm{dt}$ becomes positive (Matthews and Stephens 1998b).

\section{Effect of $\mathrm{CO}_{2}$ concentration}

Variation in the atmospheric $\mathrm{CO}_{2}$ concentration $\left(\mathrm{C}_{\mathrm{a}}\right)$ is at least partly responsible for the spatial and temporal variations in leaf $\mathrm{P}_{\mathrm{n}}$ in tea. In addition, $\mathrm{C}_{\mathrm{a}}$ is important for determining the productivity of tea in response to long-term climate change (see below). A positive, linear correlation has been observed between instantaneous $\mathrm{P}_{\mathrm{n}}$ and $\mathrm{CO}_{2}$ concentration (Smith et al. 1993). Photosynthesis can be raised temporarily up to $40-60 \mu \mathrm{mol} \mathrm{m}^{-2} \mathrm{~s}^{-1}$ by $\mathrm{CO}_{2}$ enrichment up to $1500 \mu \mathrm{mol} \mathrm{mol}^{-1}$. $\mathrm{P}_{\max }$ around $30 \mu \mathrm{mol} \mathrm{m} \mathrm{m}^{-2}$ is reached at $1000-1200 \mu \mathrm{mol} \mathrm{mol}^{-}$ ${ }^{1} \mathrm{C}_{\mathrm{i}}$ (intracellular $\mathrm{CO}_{2}$ ) in mature field-grown tea. The corresponding values for young, greenhousegrown tea are 7-10 $\mu \mathrm{mol} \mathrm{m} \mathrm{m}^{-2} \mathrm{~s}^{-1}$ and 500-600 $\mu$ mol $\mathrm{C}_{\mathrm{i}} \mathrm{mol}^{-1}$, respectively (Mohotti 1998). The $\mathrm{CO}_{2}$ response curve of mature field-grown tea is dependent on the shade and $\mathrm{N}$ supply levels (Mohotti 1998). Apart from the effect of atmospheric $\mathrm{CO}_{2}$ concentration, $\mathrm{C}_{\mathrm{i}}$ is also greatly influenced by stomatal conductance, which is highly responsive to water availability. Consequently, the $\mathrm{CO}_{2}$ available for assimilation is determined by leaf water status, and thus the whole-plant photosynthetic capacity is interrelated with water availability (see below).

\section{Effect of temperature}

The growth of the tea plant is highly affected by temperature ranges. Tea yield is sensitive to increased average monthly temperatures, and sustained periods of higher temperatures reduce tea yield.

\section{Yield response to air and leaf temperatures}

Tea grows well within an air temperature $\left(\mathrm{T}_{\mathrm{a}}\right)$ range of about $18-25^{\circ} \mathrm{C}$. Air temperatures below $13^{\circ} \mathrm{C}$ and above $30^{\circ} \mathrm{C}$ have been found to reduce shoot growth (Carr 1972). With increasing temperature above the threshold $\left(\mathrm{T}_{t}\right)$ to the optimum temperature $\left(\mathrm{T}_{\mathrm{o}}\right)$, shoot initiation rate increases and thereafter decreases with a further temperature rise up to the maximum value $\left(T_{m}\right)$. The $T_{t}$ for tea shoot extension has been found to vary from $2-7^{\circ} \mathrm{C}$ to $15^{\circ} \mathrm{C}$. Interestingly, $\mathrm{T}_{\mathrm{t}}$ for shoot extension is $2-3^{\circ} \mathrm{C}$ higher than that for shoot initiation and development (Stephens and Carr 1990). $T_{0}$ for tea has been reported in the range of $18-30^{\circ} \mathrm{C}$ and $\mathrm{T}_{\mathrm{m}}$ in the range $35-40^{\circ} \mathrm{C}$ (Carr 1972, de Costa et al. 2007).

Other important parameters influenced by $\mathrm{T}_{\mathrm{a}}$ are 'shoot extension rate' (SER) and 'shoot replacement cycle' (SRC). The latter parameter is defined as the time required for an axillary bud to be released from apical dominance (when a shoot is plucked) and to develop three leaves and a terminal bud. In the countries cultivating tea at different altitudes, e.g. Kenya, the SRC increases while the SER decreases with increasing altitude and decreasing $\mathrm{T}_{\mathrm{a}}$ (Squire et al. 1993). Temperature modifies the balance between shoot and root growth by influencing carbon allocation, so that during cooler periods carbohydrates are mostly partitioned to the roots and retranslocated to developing shoots during subsequent warmer periods (de Costa et al. 2007).

\section{Photosynthesis response}

$\mathrm{P}_{\text {max }}$ of tea leaves occurs at $30-35^{\circ} \mathrm{C}$ and rapidly falls above $37^{\circ} \mathrm{C}$, and there is no net photosynthesis at $42^{\circ} \mathrm{C}$. Considering the effect of low temperature ranges, $\mathrm{P}_{\mathrm{n}}$ reaches zero at a $\mathrm{T}_{\mathrm{a}}$ of $11-16^{\circ} \mathrm{C}$. $\mathrm{T}_{1}$ is also important in the evaluation of the temperature effect on photosynthesis. $T_{1}$ is influenced by the size, structure and the extent of exposure to the sun, wind velocity, relative humidity and rate of transpiration. The capacity for $\mathrm{CO}_{2}$ assimilation in tea decreases with increasing temperature as the day progresses from morning to early afternoon (Mohotti and Lawlor 2002). There is also an interaction between $\mathrm{P}_{n}, \mathrm{~T}_{1}$ and irrigation treatment. In well-irrigated tea, $\mathrm{P}_{\max }$ is in an optimum range of $20-30^{\circ} \mathrm{C}$, while in poorly-irrigated tea, the optimum $\mathrm{T}_{1}$ is around $20-24^{\circ} \mathrm{C}$ (Carr 1972, Smith et al. 1993, de Costa et al. 2007).

\section{Thermal duration}

Growing tea buds need to accumulate about $150^{\circ} \mathrm{C}$ days above a $\mathrm{T}_{t}$ of $12.5^{\circ} \mathrm{C}$ to expand the leaves 
and $450-500^{\circ} \mathrm{C}$-days to produce a harvestable tea shoot (Squire 1990). This parameter is needed to determine plucking rounds for different periods of the year. The thermal duration requirement for producing a harvestable tea shoot (three leaves and a bud) varies from $330-370^{\circ} \mathrm{C}$-days at high elevation to $500-600^{\circ} \mathrm{C}$-days at low elevation in Sri Lanka. The thermal duration for the initiation of one leaf, i.e. phyllochron, was estimated to be $30-40^{\circ} \mathrm{C}$-days and $60-70^{\circ} \mathrm{C}$-days at high and low elevations, respectively. In addition to the phyllochron, the plastochron, i.e. the time required for the initiation of one leaf primordium, is also affected by temperature in tea (Wijeratne 1994).

\section{Soil temperature}

Soil temperature $\left(\mathrm{T}_{\mathrm{s}}\right)$ influences the grow th of the tea plant (Carr 1972, Othieno 1982, Carr and Stephens 1992). High $T_{s}$ during the daytime associated with low $\mathrm{T}_{\mathrm{s}}$ during the night induces early flowering of the tea plant and reduces its vegetative growth. Using different types of mulch provides higher $T_{s}$ and results in higher yields (de Costa et al. 2007).

\section{Water availability}

Tea growth and productivity is mainly controlled by water availability. Drought is responsible for a $14-20 \%$ reduction in yield and $6-19 \%$ mortality of tea plants (Cheruiyot et al. 2008). In addition, under drought conditions, photoinhibition could reduce source capacity and thereby impose a sourcelimitation on tea yield (Mohotti and Lawlor 2002).

Although the total annual rainfall in most of the rain-fed growing areas is sufficient for tea production, its uneven distribution throughout the year often limits annual tea yield. Under such conditions, the distribution of rainfall throughout the year is distinctly bi-modal due to the seasonality of monsoons and, consequently, these areas experience a continuous dry period of about 2-3 months (Jaetzold and Schmidt 1983). In temperate regions that experience less than adequate rainfall, tea plantations must receive additional water from irrigation. In addition, tea cultivation areas are expanding rapidly and a large proportion of this expansion is taking place in areas whose major limitation is soil moisture. Therefore, water deficit is, and will continue to be, a major limiting factor in tea production (Cheruiyot et al. 2008).

High transpiration rates from extensive tea canopies cause significant soil water deficits which are responsible for decreased leaf expansion rates (Squire 1990, Stephens and Carr 1993). Transpiration is closely linked to photosynthesis, which is responsible for the growth of young leaves and forms the economic yield of tea (Anandacoomaraswamy et al. 2000). Since stomatal closure in response to a water deficit simultaneously limits $\mathrm{CO}_{2}$ diffusion, photosynthesis and dry matter production are both reduced under drought conditions. In tea, genotypic differences have been observed in the extent to which the stomatal conductance responds to water availability. Some deep-rooted tea genotypes are able to keep their stomata open for a longer period during a drought and allow greater uptake of $\mathrm{CO}_{2}$ and a higher $P_{n}$ (de Costa et al. 2007). To quantify the relationship between biomass production and water loss through transpiration, "water use efficiency' (WUE) or 'transpiration efficiency' (TE) has been defined. At the plot level, it is defined as WUE = total biomass/water received (through either irrigation or rain) or evapotranspiration. At the plant level, it is defined as TE = biomass/water transpired. At the leaf level, it is defined as intrinsic WUE (iWUE) $=$ the instantaneous $\mathrm{CO}_{2}$ assimilation to transpiration (Vadez et al. 2014).

It has been shown that WUE of tea is influenced by water availability and the level of nitrogen (N) application (Stephens and Carr 1991). When averaged across seasons and irrigation treatments, WUE of tea increased with increasing $\mathrm{N}$ fertilizer application, from $1.5-2.6 \mathrm{~kg} \mathrm{ha}^{-1} \mathrm{~mm}^{-1}$ in unfertilized tea to $3.3-5.2 \mathrm{~kg} \mathrm{ha}^{-1} \mathrm{~mm}^{-1}$ in tea fertilized at $225 \mathrm{~kg}$ $\mathrm{N} \mathrm{ha}^{-1}$ (Stephens and Carr 1991). It has been observed that in a cool dry season, WUE responds more to $\mathrm{N}$ fertilization, whereas under warm dry conditions, water availability becomes a greater limitation than $\mathrm{N}$ and, consequently, WUE responds more to irrigation than fertilizer application (de Costa et al. 2007).

The obtained data for TE in tea (Anandacoomaraswamy et al. 2000, Stephens and Carr 1991) are higher than the compiled ranges of TE for $\mathrm{C}_{3}$ plant species (Vadez et al. 2014) indicating a greater capacity of tea for using water more efficiently (de Costa et al. 2007). Leaf age influences leaf diffusion properties for $\mathrm{CO}_{2}$ and $\mathrm{H}_{2} \mathrm{O}$, as was shown by Sandanam et al. (1981). In well-watered plants, young leaves show a significantly lower diffusion resistance than old leaves, while in water-stressed plants young leaves always exhibit a higher diffusion resistance than old leaves (Sandanam et al. 1981). Interestingly, in the young leaves of greenhouse-grown tea which had developed under water stress, acclimation to drought conditions occurred that was well reflected in their more stable photochemistry, water relations 
and an efficient antioxidant defence system compared with the mature leaves (Hajiboland and Bastani 2012).

\section{Soil water}

Shoot extension, leaf area, stem diameter, internode elongation and the number of lateral branches of woody plants, including tea, are greatly influenced by soil water deficits (SWD) (Carr 2000). Water uptake is mainly determined by the maximum rooting depth and the water available within the root zone. Tea is generally considered to be a shallow-rooting plant. Although seedling tea has a tap root penetrating as deep as 3.0-5.5 m (Carr 2010), a major portion of the root system in clonal tea is located within the first $30 \mathrm{~cm}$ of the soil profile (de Costa et al. 2007). During drought, clonal tea develops water stress earlier than seedling tea, which is partly attributable to the differences in their root systems (Carr 1977). It has been shown that the weight of fine roots less than $1 \mathrm{~mm}$ in diameter decreased exponentially with increasing soil depth (Nixon and Sanga 1995).

The level of SWD at which plant yield as the integration of all processes begins to be significantly affected is termed the 'critical SWD'. SER, harvestable shoot density $\left(\mathrm{N}_{\mathrm{sh}}\right)$, shoot weight $\left(\mathrm{W}_{\mathrm{sh}}\right)$ and shoot $\psi \mathrm{w}$ of tea were significantly reduced when SWD exceeded 30-40 mm (Wijeratne and Fordham 1996). The reduction in tea yield caused by SWD is more due to restricted SER than reduced $\mathrm{N}_{\mathrm{sh}}$ (Stephens and Carr 1994). The critical shoot $\psi \mathrm{w}$ for a reduction in tea yield is around -0.7 to -0.8 MPa (Carr 2010).

Significant variation has been observed among different genotypes of tea in their sensitivity to drought. The drought resistant genotypes are able to maintain a greater crop canopy cover during the dry period than the susceptible genotypes (Burgess and Carr 1996).

\section{Air humidity}

In addition to SWD, a high ambient vapour pressure deficit (VPD) also reduces shoot growth in tea even when the soil is irrigated. The critical VPD affecting the growth of tea shoots has been reported to be about 1.2-2.3 kPa (Carr and Stephens 1992, Tanton 1992). Usually, shoot extension is less sensitive to dry weather than leaf expansion (de Costa et al. 2007).

The ambient VPD exerts a significant influence on the transpiration rate of a crop by controlling the water vapour pressure gradient between the leaf sub-stomatal chamber and the outside air. A greater leaf-air vapour pressure deficit results in a higher transpiration rate and consequently decreases TE (Vadez et al. 2014). Even when the soil is wet, the excessive transpiration rates resulting from higher levels of irradiance and saturation deficits around mid-day could cause transient water deficits within the plant (Smith et al. 1994).

Although the leaf appearance rate (1/phyllochron) is primarily related to $T_{a}$ (see above), it is also influenced by SWD and VPD. Similarly, water stress reduced SER from 10.78 to $6.65 \mathrm{~mm} \mathrm{wk}^{-1}$ and leaf expansion rate from 5.18 to $1.99 \mathrm{~cm}^{2} \mathrm{wk}^{-1}$ (Wijeratne 1994). All these results show that water stress reduces both the rates of leaf production, leaf expansion and shoot extension in tea and thereby reduces the number of shoots that develop up to the pluckable stage within a given time period. Consequently, yield is reduced as a result of reductions in both $\mathrm{N}_{\mathrm{sh}}$ and $\mathrm{W}_{\text {sh }}$ (de Costa et al. 2007).

\section{Effect of wind}

Some of the tea-growing regions, especially at high altitudes, experience periods of high wind speeds during certain times of the year. High wind speeds generally tend to increase transpiration rates from extensive tea canopies and thereby accelerate the development of soil water deficits during dry periods (de Costa et al. 2007). To counter these adverse effects of high wind speeds, wind breaks and shelter belts consisting of several rows of different tree species are being used in tea growing areas. However, reducing wind speed by sheltering increases canopy resistance to water vapour. Daytime temperature of the canopy increases (by $1-2^{\circ} \mathrm{C}$ ) because of the greater resistance to heat transfer from the canopy to the surrounding air (Carr 1985). Therefore, sheltering is beneficial for tea plants growing in cooler regions where $T_{a}$ is closer to the $T_{t}$ for shoot growth, under irrigation and in areas with significant advection of hot dry air onto tea fields from the surrounding areas (Carr 1985).

\section{Strategies against water stress}

Mature tea bushes with well-developed root systems withstand drought better than young tea plantations. Accordingly, during the first 3-4 years after field planting, tea bushes are prone to drought effects. Although irrigation during dry periods is a reliable solution, there are practical limitations, particularly the lack of water resources and high cost of irrigation.

Due to the long-term decline in world tea prices and rising costs of production, it is necessary to 
optimize the use of irrigation water. Strategies to reduce crop losses and minimize plant death due to drought include identifying drought resistant cultivars, expanding the irrigation infrastructure, more efficient pruning practices, mulching, increased shade-tree coverage, building water harvesting structures, drought early warning systems, and livelihood diversification (Matthews and Stephens 1998a, Duncan et al. 2016).

Development of tea cultivars that can withstand relatively low soil water content with adequate productivity is of high importance (FAO 2016, Maritim et al. 2016). First, the threshold soil water content (SWC) limit should be defined for the existing tea clones, and then the individual clones that can be productive at close to the threshold limit could be identified. This should be followed by identifying key plant indicators for desiccation tolerance in the selection of tea clones from the existing pool and development of new drought resistant tea clones for drought-prone environments (Cheruiyot et al. 2007).

Studies on drought tolerance in different tea clones have revealed that the extent of variation in the total polyphenol content could provide a basis for clonal selection. Clones that have relatively higher polyphenol content, compared to other clones, are more tolerant to drought (Cheruiyot et al. 2007). However, considering the large groups of polyphenols in tea, there are limitations in the use of total polyphenols as a reliable indicator of the response to stress and therefore there is a need to use specific compounds. Flavonoid derivatives, particularly catechins, could be more useful and should be a subject of further investigations (Cheruiyot et al. 2007).

\section{Effect of drought on tea quality}

A close correlation between shoot growth under water stress and the total polyphenol content suggests an association of plant polyphenols with stress tolerance in tea. Besides the absolute amount of polyphenols, results have shown a varied fluctuation in the polyphenol content with changes in SWC. The response of catechin variants, notably EC and EGC, positively correlates with water stress in tea. The response of EC and EGC, unlike that of ECG and EGCG, to water stress in tea can be attributed to structural differences, particularly to the absence of the carboxyl-group in EC (epicatechin) and EGC (epigallocatechin) (Cheruiyot et al. 2007). Plants under water stress produce reactive oxygen species (ROS), which are associated with tissue damage.
In order to counter the damage caused by ROS, plants produce antioxidants such as ascorbate, glutathione, carotenoid and flavonoids, among others (Hajiboland 2014). It has been shown that the molecular structure and the hydroxyl groups in particular influence the radical-scavenging activity of flavonoids (Amić et al. 2003).

\section{EFFECT OF GLOBAL CLIMATE CHANGES ON TEA PRODUCTION}

The global weather change has become unpredictable, creating uncertainty in agricultural production, with the production of tea being no exception (FAO 2016). Changes in temperature, rainfall, and the occurrence of extreme weather events such as drought and high-intensity rainfall have adversely affected yield and production of tea in recent decades (de Costa et al. 2007, Wijeratne et al. 2007b, Duncan et al. 2016). Drought events in the region are primarily due to a weak southwest monsoon on the Indian sub-continent, leading to a failure of wet season rainfall (FAO 2016). Drought affects both the quantity and quality of tea, leading to a considerable loss of export earnings. Production costs can also increase during drought due to the need for additional inputs (Wijeratne and Fordham 1996). A report on climate change in Asia predicts a $10 \%$ extension of the dry and wet seasons in the main tea plantation area by 2070 , together with an increased frequency and severity of extreme weather events. Temperature increases of 0.4 to $3.0^{\circ} \mathrm{C}$ are also predicted, while rainfall is expected to increase with an uneven pattern of distribution (FAO 2016).

The intensity of these climate impacts on tea production will likely vary across the major tea growing regions, in low-, up- and mid-country areas (Wijeratne et al. 2007a). Prior research has also identified eight agro-ecological tea-growing areas which are most vulnerable to climate change (Wijeratne and Chandrapala 2013).

Long-term gradual climate change involves increasing $\mathrm{C}_{\mathrm{a}}$ and the consequent warming of the atmosphere. The rising $T_{a}$ triggers a variety of changes in the atmosphere leading to modified rainfall patterns, evapotranspiration rates and VPD. Because of the close relationships between tea yield and these atmospheric variables, long-term climate change is likely to cause significant impacts on the key physiological and developmental processes that determine the yield and yield components of tea (Wijeratne 1996). Both positive and negative responses to different components of climate 
change can be observed. A clear positive effect is the response to increased $\mathrm{C}_{\mathrm{a}}$ through increased photosynthetic rates and yields. However, there can be substantial genotypic variation in the response to increased $\mathrm{C}_{\mathrm{a}}$. Genotypic variation in response to elevated $\mathrm{C}_{\mathrm{a}}$ has been reported for other crops and natural plant species (Poorter and Navas 2003) as well. In two $\mathrm{CO}_{2}$ fertilization field experiments carried out over a period of 18 months at low (60 m a.s.1.) and high (1380 $m$ a.s.l.) elevations in Sri Lanka, Wijeratne et al. (2007a) showed that an increase in $\mathrm{C}_{\mathrm{a}}$ from the present ambient level of $370 \mu \mathrm{mol} \mathrm{mol}^{-1}$ to $600 \mu \mathrm{mol}$ mol $^{-1}$ increased tea yields by 33 and $37 \%$ at the high and low elevations, respectively. Increases in both $\mathrm{N}_{\text {sh }}$ and $\mathrm{W}_{\text {sh }}$ contributed to these increases in yield. In addition to $\mathrm{C}_{\mathrm{a}}$, several other climate changeinduced variables have been identified and used in simulation models to predict the impacts of climate change on tea yield at different altitudes (Wijeratne et al. 2007a). The predicted tea yields by the year 2050 under the climate change scenarios specified by these models showed increased yields at higher altitudes, but reduced yields at lower altitudes (de Costa et al. 2007).

\section{MOLECULAR GENETIC STUDIES ON TEA PLANTS UNDER STRESS}

Cultivated tea is diploid $(2 \mathrm{n}=2 \mathrm{x}=30)$ (Bezbaruah 1971 ) with a relatively large genome size of about 4.0 GB (Tanaka and Taniguchi 2006). To enable investigation of the molecular mechanisms involved in the response of tea to various stresses, several classes of genes have been characterized including those responsible for regulation, signalling and cellular adaptation. A better understanding of the genetic basis of stress tolerance in tea is essential for enhancing the efficiency and effectiveness of tea breeding programmes. In relation to drought, $d r l$, $d r 2$ and $d r 3$ drought responsive ESTs (expressed sequence tags) from leaf tissues have been reported using the differential display technique (Sharma and Kumar 2005). In addition, 572 ESTs from young roots of drought tolerant tea cultivars have been introduced using the suppression subtractive hybridization (SSH) technique (Das et al. 2012). The ESTs are responsible for cell rescue, defence, cellular transport, metabolism, energy, protein synthesis, cell cycle and DNA processing, signal transduction, transcription and biogenesis of cellular components in drought-stressed tea (Muoki et al. 2012). In a drought tolerant cultivar, chaperones and defence-related genes, traumatin- like proteins, chitinase and heat-shock proteins were over-expressed in leaf tissues as compared to a susceptible cultivar (Muoki et al. 2012). As a result of this technique, sequencing of cDNA library clones, generation and analysis of ESTs provided an mRNA expression profile and a rapid, low-cost and efficient way to identify functional genes. Apart from the 7084 drought-related ESTs in tea, one genome survey sequence, 158 sequences reads archives (SRA), and 38789 proteins have been deposited in the Gene Bank (Maritim et al. 2016). Several genes including heat-shock proteins (HSP70), superoxide dismutase, catalase, peroxidase, calmodulin-like protein ( $\mathrm{Cam} 7)$ and galactinol synthase (Gols4) were induced in plants exposed to drought. Additionally, the expressions of HSP70 and superoxide dismutase were higher in the tolerant cultivar relative to the susceptible cultivar under drought conditions (Maritim et al. 2016).

The proteomic profiles of tea plants under $\mathrm{Al}$ treatment using proteomics approach revealed 755 and 1059 differentially expressed proteins in tea roots and leaves, respectively. Proteins involved in phenylpropanoid and lignin metabolism are differentially changed in the roots, while proteins involved in photosynthesis were all stimulated in the leaves. Enzymes involved in glutathione metabolism and citrate synthesis related to the TCA cycle were accumulated in tea roots in response to $\mathrm{Al}$ (Xu et al. 2017).

\section{NUTRITIONAL REQUIREMENTS FOR TEA PRODUCTION}

Plants need adequate amounts of nutrients for optimum growth and productivity. The use of fertilizers in crops is important for increasing yields and influencing soil properties. Fertilizer application is a common management practice in tea production and significantly improves the yield and quality of tea (Qiu et al. 2014, Venkatesan et al. 2004).

Harvesting of plants removes nutrients from the soil. In tea, the rate of nutrient removal depends on the duration of plucking rounds and their intensity. Continuous plucking of the tea leaves leads to the mining of the macronutrients $\mathrm{N}, \mathrm{P}$ and $\mathrm{K}$, thus making it necessary to replenish the nutrients to the plant (Tabu et al. 2015). The harvestable portion of the tea plant contains a high percentage of nutrients, nitrogen $(\mathrm{N})$ being the most abundant nutrient followed by potassium $(\mathrm{K})$, calcium $(\mathrm{Ca})$, phosphorus $(\mathrm{P})$, sulfur $(\mathrm{S})$, magnesium $(\mathrm{Mg})$ and zinc ( $\mathrm{Zn}$ ) (Sultana et al. 2014). The influence of 
an applied fertilizer on tea yield arises from its effects on the shoot extension rate and the rate of regeneration (Mokaya 2016).

\section{Macronutrients}

\section{Nitrogen}

Nitrogen $(\mathrm{N})$ plays a key role in the growth of plants and it is the most deficient mineral element in the soil (Hawkesford et al. 2012). Nitrogen nutrition enhances the yield in tea under favourable conditions of temperature, relative humidity, rainfall and evaporation without any adverse effects of large amounts of $\mathrm{N}$ supply (Owuor 1997). Favourable yields ranging from 5800 to $6400 \mathrm{~kg}$ made tea ha-1 per year in high-yielding clones have been obtained with increasing $\mathrm{N}$ supply of up to $600 \mathrm{~kg} \mathrm{ha}^{-1}$ year $^{-1}$. The incredible response of the tea plant to heavy applications of nitrogen fertilizers is stimulated by frequent harvesting of the shoots (Ruan and Wu 2004, Cheruiyot et al. 2009).

Nitrogen deficiency in tea leads to the shortening of the internodes and the leaves are lighter than the normal green colour in young flush (TRFK 2002). Nitrogen is deficient in the tea plant when the leaf $\mathrm{N}$ content is less than $3 \%$, mildly deficient when it is $3.0-3.5 \%$, and sufficiently supplied when it is more than 3.5\% (Owuor 1997). In addition to the low level of nitrogen in the soil, lower ability of feeder roots to take up $\mathrm{N}$ from the soil is the main reason for $\mathrm{N}$ deficiency in tea. During a drought season roots die out, and during a cold season the growth rate of roots is greatly impaired (Owuor 1997).

An increase in NR activity due to the increase in $\mathrm{N}$ or $\mathrm{K}$ fertilizer doses has been noted (de Costa et al. 2007). There is a significant correlation between green leaf yield and NR activity determined during the first and second harvesting rounds after fertilizer application (Venkatesan and Ganapathy 2004). In the tea grown in a nutrient solution, the photosynthetic rate $\left(\mathrm{P}_{\max }\right)$ and photochemical efficiency increased with increasing $\mathrm{N}$ supply up to $105 \mathrm{ppm} \mathrm{N}$ (de Costa et al. 2007). Interestingly, the response in $\mathrm{P}_{\max }$ was observed immediately after applying the $\mathrm{N}$ treatments, but the response in photochemical efficiency was not observed until after one month (de Costa et al. 2007).

The tea plant is well-adapted to $\mathrm{NH}_{4}$-rich environments and thus prefers $\mathrm{NH}_{4}^{+}$to $\mathrm{NO}_{3}^{-}$, which is associated with a high capacity for $\mathrm{NH}_{4}^{+}$ assimilation in their roots. The poor plant growth with $\mathrm{NO}_{3}^{-}$is largely associated with inefficient absorption of this N source (Ruan et al. 2007). In tea plantations, $\mathrm{N}$ fertilizers are applied in the form of $\mathrm{NH}_{4}^{+}$or urea (Ruan and $\mathrm{Wu} 2004$ ); however, substantial nitrification and a large pool of $\mathrm{NO}_{3}^{-}$in tea soils of very low $\mathrm{pH}$ have been detected (Ruan et al. 2007). Recently, by using the scanning ionselective electrode technique it has been shown that tea roots had a preference for $\mathrm{NH}_{4}^{+}$and that the presence of $\mathrm{NO}_{3}^{-}$had a negative effect on $\mathrm{NH}_{4}^{+}$ influx, while $\mathrm{NH}_{4}^{+}$had a positive effect on $\mathrm{NO}_{3}^{-}$ influx (Ruan et al. 2016).

\section{Phosphorous}

Phosphorus (P) is an essential macro-nutrient and plays a crucial role in the cellular structure and energy metabolism in higher plants (Hawkesford et al. 2012). Phosphorous plays a major role in the formation of new wood and roots in tea. Phosphorus deficiency in tea manifests itself as the absence of brightness, particularly in mature leaves, and dieback of young and old woody stems (TRFK 2002). Under moderate soil $\mathrm{pH}$ of about 5.5 to 7.0, $\mathrm{P}$ availability to plants is high, but decreases at $\mathrm{pH}$ below 5.5 or above 7.0 (Hamid 2006). In very acidic soils, $\mathrm{P}$ is absorbed onto hydroxides of $\mathrm{Fe}$ and $\mathrm{Al}$ and becomes unavailable to plants. The lack of mobility of the phosphate ion makes $\mathrm{P}$ uptake dependent on root development (Neumann and Römheld 2012).

Several workers in different tea growing countries have attempted to determine the optimum requirements of a phosphate fertilizer. The majority of these workers reported a relatively low increase in yield, or even no response to a P fertilizer in tea (Konishi et al. 1985, Ruan et al. 2000). Addition of $P$ fertilizers at higher levels has been recommended by some authors to provide an excess over that lost by precipitation, and it has been stated that yield responses can occur only to heavy applications (Konishi et al. 1985). In a greenhouse study, it has been observed that the tea plant is a species extremely tolerant to $\mathrm{P}$ deficiency and that the $\mathrm{P}$ requirement for an optimum growth is as low as $50 \mu \mathrm{M}$ in a hydroponic medium, which is much less than the $\mathrm{P}$ requirement for optimum growth for many other crop species (Salehi and Hajiboland 2008). A high internal use efficiency (Salehi and Hajiboland 2008) that is attributable at least partly to a high rate of re-translocation of $\mathrm{P}$ from mature to young growing leaves (Hajiboland and Salehi 2014) is the main mechanism responsible for the low $\mathrm{P}$ requirement in tea.

\section{Potassium}

Potassium (K) is the most important nutrient to tea after nitrogen. Like with N, large amounts of $\mathrm{K}$ are removed from the soil through harvesting and the 
tea plant has a moderate to high requirement for $\mathrm{K}$ (Hamid 2006, Sultana et al. 2014). Tip and margin burn in mature leaves, depletion of the starch reserve in the roots and accumulation of nitrates, degeneration of feeder roots and dieback occur under K deficiency (TRFK 2002, Jessy 2010). In a K-deficient tea bush, the branches are thin and weak, and the recovery from pruning takes more time.

\section{Micronutrients}

Current fertilizer recommendations for tea have always emphasized macronutrients, and despite the continuous removal through harvesting, like with macronutrients, micronutrients have not been taken into consideration. The availability of micronutrients is affected by different factors, particularly soil and rhizosphere $\mathrm{pH}$. High soil $\mathrm{pH}$ results in the retention of micronutrients in the soil, thus limiting their uptake by tea plants (Rengel 2015).

\section{Zinc}

Zinc ( $\mathrm{Zn})$ deficiency in the soil is common on soils with different $\mathrm{pH}$ values in the world. Excessive application of phosphate fertilizers induces $\mathrm{Zn}$ deficiency (Broadley et al. 2012). Zinc deficiency in tea plants leads to high mortality and stunted growth. Young leaves in a $\mathrm{Zn}$-deficient tea plant appear narrow, erect and form a rosette at the apex of the stem (Nelson 2006). Application of Zn improves the chlorophyll content, net photosynthetic rate and water use efficiency, and consequently increases made tea yield (Kumar et al. 2014). Zinc deficiency can be corrected by foliar application, while application to the soil is not effective. In contrast to $\mathrm{Zn}, \mathrm{Fe}$ availability is sufficient in acid soils, but high levels of $\mathrm{Fe}$ induce $\mathrm{Cu}$ deficiency (Sultana et al. 2014).

\section{Boron}

Boron (B) deficiency and the effect of B fertilizers on the growth and yield of tea have been extensively studied (Njoloma 2012, Kumar et al. 2014). The boron content in the soil has been found to decrease with the age of tea plantation. High incidence of $\mathrm{Cu}, \mathrm{B}$ and $\mathrm{Zn}$ deficiencies in tea leaves was reported from approximately 170 mature clonal tea fields in Malawi (Njoloma 2012). Soil analyses from 11 districts of Assam and 4 districts of West Bengal revealed B deficiency in $17 \%$ and $64 \%$ of the samples, respectively (Baruah et al. 2011). The authors showed that although some of the surface soil samples in Assam had B below the detection limit, the deficiency was associated with the pollution of drinking water sources in this area due to the leaching of B from surface soils beyond the root zone during monsoon rains (Baruah et al. 2011).

Since the range of soil B concentrations between deficiency and toxicity symptoms is very narrow (Broadley et al. 2012) and the majority of data from field studies did not show considerable improvement in tea yield by B application either to the soil or leaves, application of B fertilizers to tea gardens is not routinely recommended for many of the tea growing areas. Excessive boron can cause off-colours and stunting of tea plant growth. By increasing boron concentrations in plant tissue to toxic levels, mature leaves exhibit leaf-edge burning and necrosis, and may develop black spots (Baruah et al. 2011). In addition, adverse effects for human health of high B content in tea infusion (Zioła-Frankowska et al. 2014) raises concerns about the application of B fertilizers to tea fields.

In tea plants grown hydroponically under greenhouse conditions, visual B deficiency symptoms were observed as reduced shoot height in 30-35 treatments. Leaf-affecting symptoms appeared only in young leaves and included reduced surface area, dark green colour and, rarely, curling of the leaf lamina. The roots of B-deficient plants were poorly branched and tended to turn light purple. Boron-deficient plants had up to $40 \%$ lower shoot and root dry weight. The number of leaves and the height of shoots were also reduced by about $42 \%$ and $17 \%$, respectively (Hajiboland et al. 2011). The data of the greenhouse study on tea revealed that a considerable re-translocation of B occurs from mature to growing leaves. In relation to potential B mobilizing and/or complexing compounds, it has been observed that sucrose, glucose, and fructose exist in the leaf exudate and phloem sap, while xylitol, sorbitol, mannitol, maltose, galactose, cellobiose or raffinose are not found, indicating a considerable re-translocation of B in the tea plant despite its lacking polyol compounds (Hajiboland et al. 2013b).

In general, B deficiency is intensified under drought conditions due to lower B mobility in the soil (Broadley et al. 2012). In turn, low-B plants are susceptible to drought stress because of lower shoot-root translocation and less re-translocation from mature to young leaves (Hajiboland and Bastani 2012). Although B-deficient plants are more conservative in relation to water loss following elevated stomatal limitation, their water potential 
is lower than in B-sufficient plants, irrespective of the watering regime, because of lower water uptake (Hajiboland and Bastani 2012). Boron deficiency reduces root hydraulic conductivity (Apostol and Zwiazek 2004), likely due to disturbance in the formation of functional xylem vessels (Broadley et al. 2012). A decline in root hydraulic conductance may also be caused by a reduction in new root growth in B-deficient plants. Under the combined effects of $\mathrm{B}$ deficiency and water stress, the reduction in $\mathrm{CO}_{2}$ assimilation is mainly related to non-stomatal factors (Hajiboland and Bastani 2012).

\section{Aluminium}

Aluminium (Al) is the third most abundant metallic element; however, it is only available to plants under a low $\mathrm{pH}$ of 5.5 and below. In acid soils, Al becomes increasingly available, leading to toxicity for the majority of plants except for tea and other accumulator species. For non-accumulating species, Al toxicity decreases the uptake and utilization of $\mathrm{P}$ by fixing it through an absorption-precipitation reaction. Aluminium causes Ca deficiency in plants due to the disruption of its uptake and translocation (Poschenrieder et al. 2008, 2015).

The tea plant accumulates up to $6866 \mathrm{mg} \mathrm{kg}^{-1} \mathrm{Al}$ in old leaves, but in young leaves, $\mathrm{Al}$ concentration is much lower ( $\left.\sim 380 \mathrm{mg} \mathrm{kg}^{-1}\right)$ (Carr et al. 2003). Aluminium promotes the growth of tea bushes (Ghanati et al. 2005, Hajiboland et al. 2013a). A more than threefold increase in root biomass was observed in tea plants supplied with $300 \mu \mathrm{M}$ $\mathrm{Al}\left(125 \mu \mathrm{M} \mathrm{Al}{ }^{3+}\right.$ activity). Total root length was positively correlated with root $\mathrm{Al}$ concentrations $(r=0.98)$. Greater root surface area may improve water and nutrient uptake by the plants. Al-induced growth stimulation in tea was mediated by a higher photosynthetic rate and increased antioxidant defence (Hajiboland et al. 2013a). Oxidative stress in tea plants that are not exposed to Al has been related to $\mathrm{Fe}$ toxicity. In the absence of $\mathrm{Al}$, tea roots accumulate $\mathrm{Fe}$ up to toxic levels and its concentration in young leaves reached up to 1000 $\mu \mathrm{g} \mathrm{Fe} \mathrm{g}^{-1}$ dry weight, which is above the Fe-toxicity threshold in most species. The supply of Al reduced Fe uptake and transport. These results indicate that Al-induced growth stimulation might be due to the alleviation of a latent $\mathrm{Fe}$ toxicity occurring in tea plants without Al supply (Hajiboland et al. 2013c).

Interestingly, growth in B-deficient plants is completely resumed by Al supplementation, or even surpasses the control plants in terms of shoot biomass (Hajiboland et al. 2014). It has been demonstrated that up-regulation of $\mathrm{C}$ and $\mathrm{N}$ metabolism and enhancement of $\mathrm{B}$ uptake and transport are mechanisms for growth amelioration in B-deficient tea plants by Al supplementation (Hajiboland et al. 2014).

\section{Effect of nutrient supply level on tea quality}

The quality of both green and black tea is influenced by the level and form of $\mathrm{N}$ supply to tea plants (Ruan 2005). The quality of green tea progressively increases with $\mathrm{N}$ supply and producers of green tea, e.g. in Japan, apply up to $1200 \mathrm{~kg} \mathrm{~N} \mathrm{ha}^{-1}$ per year to maximize its quality (Owuor 1997). Green tea quality and its flavour components are greatly influenced by the concentrations of free amino acids, fatty acids, polyphenols (mainly catechins) and caffeine. There is a positive relationship between $\mathrm{N}$ concentration and the accumulation of these qualityrelated components of tea plants (Ruan 2005). In tea plants grown hydroponically, concentrations of free amino acids were considerably higher in $\mathrm{NH}_{4}^{+}$- than in $\mathrm{NO}_{3}^{-}$-fed plants. Furthermore, the relative allocation of absorbed $\mathrm{N}$ to free amino acids, particularly theanine and glutamine, was substantially increased by $\mathrm{NH}_{4}^{+}$nutrition. It has also been reported that raising the $\mathrm{N}$ supply leads to a higher arginine concentration and consequently less favourable taste of the green tea produced (Ruan et al. 2007).

In contrast to green tea, black tea quality significantly declines with an increase in $\mathrm{N}$ supply in some aspects, including flavour quality (Owuor et al. 2000). Thus, the optimum $N$ supply for maximum tea yield produces poor quality black tea. Increased N supply reduces catechin levels in tea shoots, leading to low formation of theaflavins and thearubigins, which are critical parameters of black tea quality. High $\mathrm{N}$ has also been demonstrated to increase the levels of unsaturated fatty acids and also to reduce the ratio of the Group II : Group I volatile flavour compounds, all of which depress black tea quality. The recommended optimum $\mathrm{N}$ rate which compromises for better yield and quality of black tea is in the range of $100-200 \mathrm{~kg} \mathrm{~N} \mathrm{ha}^{-1}$ year $^{-1}$ (Owuor et al. 2000, Owuor et al. 2006).

In relation to micronutrients, leaf copper $(\mathrm{Cu})$ and $\mathrm{Zn}$ are important factors in determining the fermenting characteristics of the tea leaf and therefore the quality of the final product (Ogunmoyela et al. 1994). Application of fertilizers as a combination of $\mathrm{N}, \mathrm{K}$ and micronutrients improves the caffeine content of tea leaves. In another report (Njoloma 2012), it was observed 
that thearubigin (TR) concentration was the only biochemical quality parameter that was affected by micronutrient $(\mathrm{Cu}, \mathrm{Zn}$ and $\mathrm{B})$ foliar sprays. An increase in the Thearubigin/Theaflavin (TR/ $\mathrm{TF}$ ) ratio by a foliar spray of $\mathrm{Cu}, \mathrm{Zn}$ and $\mathrm{B}$ indicated that more catechins were being converted to TRs than TFs during fermentation (Njoloma 2012).

In greenhouse-grown tea plants, modification in the metabolism of phenolic compounds under B deficiency conditions has been observed as a rise in phenylalanine ammonia lyase activity in young leaves. However, the activity of polyphenol oxidase, which catalyzes the oxidation of catechins to theaflavins and thearubigins, was only marginally affected in the young leaves of B-deficient tea plants. Soluble phenolics fraction was increased up to 3.4fold in the young leaves, but it was not influenced by $\mathrm{B}$ nutrition in the old leaves and roots. Cell wallbound phenolics and lignin content was lower in B-deficient plants compared with B-sufficient ones (Hajiboland et al. 2015).

\section{Environmental consequences of intensive use of fertilizers in tea production}

The current application rates of $\mathrm{N}$ fertilizers in tea fields are usually beyond $800 \mathrm{~kg} \mathrm{~N} \mathrm{ha}^{-1}$ year $^{-1}$ and in some cases even reach $2500 \mathrm{~kg} \mathrm{ha}^{-1}$ year $^{-1}$, which means that they are much higher than those in other crop fields (Hirono and Nonaka 2014). Out of the inorganic NPK applied annually, only $25-50 \%$ are taken up by plants and the rest is lost through leaching, erosion, denitrification or volatilization (in the case of $\mathrm{N}$ ), or is immobilized in soil organic matter (Roberts 2008).

The heavy fertilizer input influences negatively the water quality in tea producing regions. It has been found that a high concentration of nitrate is drained back to ponds around tea fields and excessive leaching leads to underground water pollution (Tanaka et al. 2002, Hirono et al. 2009). In addition, the nitrous oxide emission potential is significantly high in tea fields with an $\mathrm{N}$ application rate of over $1000 \mathrm{~kg} \mathrm{ha}^{-1}$ year $^{-1}$ (Hirono and Nonaka 2012).

Nutrient use efficiency of a crop is the yield obtained per unit of available nutrient in the soil (Hirel et al. 2011). It has been found that the nutrient use efficiency with regard to NPK is significantly enhanced by the application of NPK fertilizer in a tablet form as a slow release fertilizer (Jagadeeswaran et al. 2005). In order to reduce nitrate leaching, it has been recommended to use coated $\mathrm{N}$ fertilizers in tea fields. Calcium cyanamide $\left(\mathrm{CaCN}_{2}\right)$ is a slow release form of $\mathrm{N}$ that improves soil fertility and reduces the infestation of the soil with soil-borne pathogens and weeds (Oh et al. 2006). Compared with the conventional high $\mathrm{N}$ treatment (1100 $\left.\mathrm{kg} \mathrm{N} \mathrm{ha}^{-1}\right)$ without lime, the low $\mathrm{N}$ application rate $\left(400 \mathrm{~kg} \mathrm{~N} \mathrm{ha}^{-1}\right)$ with $\mathrm{CaCN}_{2}$ effectively reduces soil acidification and produces the same or slightly higher levels of tea yield and the total $\mathrm{N}$ and amino acid content of tea leaves $(\mathrm{Oh}$ et al. 2006).

\section{Soil pH and microbial ecology of soils}

Continuous use of ammonium $\mathrm{N}$ fertilizers in tea fields leads to a lower soil $\mathrm{pH}$ (Thenmozhi et al. 2012). Under such conditions, a reduction in $\mathrm{K}, \mathrm{Mg}$ and $\mathrm{Ca}$, and an increase in the levels of manganese $(\mathrm{Mn})$ and $\mathrm{Al}$ availability results in nutrient imbalance in tea plants (TRFK 2012). Soil acidity increases with increasing tea cultivation period. Soil $\mathrm{pH}$ in tea plantations decreased by $1.37,1.62$ and 1.85 after 13,34 and 54 years, respectively, compared to the soil of an unused land (Wang et al. 2010). Soil acidification rate at the early stages of tea cultivation is higher than at the later stages. The acidification rate for a period of $0-13$ years was found to be $4.40 \mathrm{kmol} \mathrm{H}^{+} \mathrm{ha}^{-1}$ year $^{-1}$ (Wang et al. 2010). Low soil $\mathrm{pH}$ has an adverse impact on the microbial community structure, biomass and its functioning in tea soils, particularly in old plantations with intensive tea production (Han et al. 2007).

The availability and concentration of macronutrients increases with an increase in soil $\mathrm{pH}$ (Nath 2013). The requirement of young tea plants for inorganic fertilizer can be reduced by the use of poultry manure, while the requirement of mature tea plants for chemical fertilizer can be minimized or avoided by the use of cow dung, as mature tea plants require more $\mathrm{N}$ and $\mathrm{P}$ compared to the younger ones (Sultana et al. 2014).

\section{Effect of fertilizer on induction of drought stress}

A high $\mathrm{N}$ application rate increases the yield of tea only under optimum irrigation (Carr 1972). It was found that high application rates of $\mathrm{N}$ fertilizer raise the optimal soil water content required by tea plants and subsequently lower tea productivity and survival during drought (Cheruiyot et al. 2009). A rate of $\mathrm{N}$ fertilizer application above $200 \mathrm{~kg} \mathrm{ha}^{-1}$ limits the growth and yield of tea during a drought season (Ng'etich 1999). The lack of tolerance to water stress in well-fertilized tea plants is mainly due to the modification of assimilate partitioning leading to an increased leaf-to-root mass ratio 
as well as to a reduction in soil-plant hydraulic conductivity (Cheruiyot et al. 2009).

\section{PROTECTION OF TEA FROM DISEASES AND PESTS}

The economic loss in tea due to diseases is generally higher compared to the losses caused by pests. The pressure of diseases and pests on tea production depends on the control strategy and also on the agro-ecological environment and the altitude of the plantation. One way of reducing pesticide application is to escape excessive pressure from specific diseases or pests by growing tea in environments less favourable to pests and diseases (Rattan 1992, Lehmann-Danzinger 2000, Hazarika et al. 2009).

During recent decades, high tea yields have been achieved by eliminating shade trees in many tea-growing countries, which increases the weed problem, the need for synthetic fertilizers and the incidence of some pests and diseases. In order to reduce labour intensity, manual weeding has been replaced with herbicides, thereby introducing the risk of herbicides in the plucked tea leaves. However, the need for shading tea plants is controversial. Cultivating tea in full sunlight or with reduced shade not only results in higher yields but also reduces the severity of the main disease of tea plants in Asia, the blister blight (Exobasidium vexans). This also applies to the infestation by the tea mosquito bug (Helopeltis sp.). In contrast, the leaves falling from shade trees have a favourable impact on the organic matter in the soil, which is important for the diversity and population density of the soil microflora and fauna. The spreading and incidence of root disease and also of nematodes is favoured by a disturbed soil microflora with lower species diversity and a low population density of antagonists to the fungal root disease agents (Rattan 1992, Lehmann-Danzinger 2000, Hazarika et al. 2009).

Tea cultivation is a plantation culture, with a single tea bush remaining on the same site for a very long time, e.g. $>50$ years. The healthy survival of a tea bush for a long time on the same site requires a good equilibrium and a high degree of integration with the environment. However, this is not possible in highly efficient plantations due to the intensive management practices.

There is a growing demand for residue-free tea, particularly in the developed countries; thus, one of the challenges for tea growers nowadays is to produce tea without pesticide residues. The demand of the market for quality and the demand of the producer for high yield with a low labour input are mainly incompatible (Willer et al. 2008, Darnhofer et al. 2010).

\section{ORGANIC TEA PRODUCTION}

An organic product is free of extraneous chemicals, antibiotics, synthetic hormones, genetic modifications and is minimally processed without artificial additives, preservatives or irradiation (Willer et al. 2008, Darnhofer et al. 2010). Organic agriculture reduces air, soil and water pollution and optimizes the mutual reliance of plants, animals and people. Through organic agriculture there is enhanced sustainability, thus provision of quality products to present and future generations is assured. Organic management of the production process results in increased soil fertility, better soil stability, improves soil bulk density and soil porosity and water retention, thus reducing the need for irrigation. In organic agriculture, the main sources of nutrients include animal dung, compost and green manure. Organic fertilizers improve the chemical, physical and biological characteristics of the soil, thus increasing the yields and subsequently ensuring sustainability (Willer et al. 2008, Darnhofer et al. 2010).

Increasing the awareness of health and environmental advantages of organic agriculture was the main cause for the growth in the sales of organic food by $17-22 \%$ during the last decade (Wanyoko et al. 2011). Since the introduction of organic tea production in the world there has been an increasing demand for organic tea compared to conventional tea (IFOAM 2016, Williges 2004). Organic tea cultivation ensures the production of safe teas for the consumer in a sustainable way, with an objective of conserving the ecosystem and natural habitat without polluting the air, water and soil. Sources of organic material in organic tea production include animal manures, crop residues, compost and green manures (Sultana et al. 2014). The organic sources of nutrients in tea production are cheap and easily available without negative effects to the environment. In a comparative study between organic and conventional farming systems by Chin et al. (2010) it was found that tea obtained from organic farming systems had a significantly higher polyphenol content in shoots, but showed no significant difference in the caffeine, epicatechin, epicatechin gallate and epigallocatechin content. It has been stated that the antioxidant content of tea 
extract from organically grown tea is higher than that of conventional tea (Bagchi et al. 2015).

Organic production of tea starts right from the field site selection and continues through agronomic practices in the field, production at the factory, packaging, until the product reaches the end user. The International Federation of Organic Agriculture Movements (IFOAM) sets the basic organic standards for different regions, countries and organizations. For a product to be declared as organic it has to be certified by a state or private agency that has been accredited by the state. Therefore, organic tea gardens are certified by a recognized organic certification body stating that the garden has met the requirements of organic agriculture and cultivation in harmony with nature and ecological disciplines (Ping et al. 2014). The certification process ensures that the production process is performed under the minimum standards of organic production. The third party certifier investigates the whole process from the point of production, the environment, to the point where it reaches the consumer, to ensure that the standards are met (IFOAM 2016).

There are major challenges that affect the adoption of organic tea farming. According to the certification standards, the farm has to remain in production without the use of any inorganic input for three years before being declared organic. In this period there is a decline in the yield before the field recovers and starts benefitting from the organic practices (Karki et al. 2011). The site selected for organic tea cultivation should be isolated so that there is no possibility of any drift reaching the field; thus, there should be a buffer zone separating organic farms from the conventional ones (Karki et al. 2011).

Although organic fertilizers are available in the form of animal waste and compost, they are not widely used by farmers (Waarts et al. 2012). One of the constraints is that the manure should be kept moist under a roof to avoid volatilization of $\mathrm{N}$ in gaseous forms (Sultana et al. 2014).

In organic tea production, weeds are controlled by hand pulling, slashing and other cultural practices that reduce the emergence of weeds, for example, mulching (Kutama et al. 2013). Weed control in young tea plantations is more difficult than in mature ones because the exposure of weed seedlings to sunlight is higher when tea bushes are still young. Late removal of weeds in young tea plantations has a significant effect on the maturity stage of the crop (TRFK 2002). Hand weeding of perennial grasses such as Digitaria scalarum is not appropriate (TRFK 2002), and removing them with hoes, jembes or fork jembes leads to damage of tea feeder roots. Organic production of tea is difficult to be practiced by small-scale farmers. These farmers collect the green leaf together at a common point for delivery to a given factory for processing. Thus, all the farmers have to accept the whole idea of organic production and the farmers have to be managed to ensure control of the production process (Karki et al. 2011). In a study by Karki et al. (2011) on the factors influencing the conversion to organic farming it was noted that there was a relationship between the size of the farmland and the willingness of the farmer to adopt organic farming practices. Farmers with large acreages of land were more willing to take the risk and bear the initial cost of certification that comes with organic farming.

Because adoption of a new technology is faster amongst the farmers who are literate, the level of education amongst the farmers is a hindrance to accepting an organic production system. Organic agriculture involves a lot of record keeping for certification purposes (Karki et al. 2011) and this is likely to discourage many farmers who are illiterate.

\section{CONCLUSIONS}

1. Specific environmental and soil conditions required for tea production, including high humidity and acidic soil, have restricted the cultivation of tea to a few countries in Asia and Africa. Global environmental changes, particularly the reduction in rainfall and/or its poor distribution throughout the year, are becoming important constraints in tea cultivation within the tea-growing countries.

2. Large amounts of fertilizers need to be applied to obtain a high yield of tea; however, they increase environmental risks such as groundwater pollution, soil acidification, and $\mathrm{N}_{2} \mathrm{O}$ emission. New methods of fertilizer application and the use of new fertilizers are putative goals for sustainable tea production.

3. Because of the high incidence of pests and pathogens due to high humidity in tea-growing areas, applying fungicides and pesticides is unavoidable in tea cultivation. Nevertheless, increasing concerns regarding the quality of tea have resulted in producers restricting the use of chemicals in organic tea produced worldwide. 


\section{REFERENCES}

Amić D., Davidović-Amić D., Bešlo D., Trinajstić N., 2003. Structure-radical scavenging activity relationships of flavonoids. Croat. Chem. Acta 76: 55-61.

Anandacoomaraswamy A., DE Costa W.A., Shyamalie H.W., Campbell G.S., 2000. Factors controlling transpiration of mature field-grown tea and its relationship with yield. Agric. For. Meteorol. 103: 375-386.

Anandacoomaraswamy A., de Costa W.A.J.M., Tennakoon P.L.K., Van Der Werf A., 2002. The physiological basis of increased biomass partitioning to roots upon nitrogen deprivation in young clonal tea (Camellia sinensis (L.) O. Kuntz). Plant Soil 238: $1-9$.

Anesini C., Ferraro G.E., Filip R., 2008. Total polyphenol content and antioxidant capacity of commercially available tea (Camellia sinensis) in Argentina. J. Agric. Food Chem. 56: 9225-9229.

Apostol K.G., ZwiazeK J.J., 2004. Boron and water uptake in jack pine (Pinus banksiana) seedlings. Environ. Exp. Bot. 51: 145-153.

Bagchi A., Ghosh B.C., Swain D.K., Bera N., 2015. Organic farming practice for quality improvement of tea and its anti-Parkinsonism effect on health defense. J. Phys. Chem. Biophys. 5: 1-5.

BARUA D.N., 1969. Seasonal dormancy in tea (Camellia sinensis L.). Nature 224: 514.

Baruah B.K., Haque A., Das B., Medhi C., Misra A.K., 2011. Boron in soil and water samples in some tea garden belt of Golaghat district, Assam. Adv. Appl. Sci. Res. 2: 298-305.

Bezbaruah H.P., 1971. Cytological investigation in the family Theacea - I. Chromosome numbers in some Camellia species and allied genera. Caryologia 24: 421-426.

Broadley M., Brown P., Cakmak I., Rengel Z., Zhao F., 2012. Function of nutrients: Micronutrients. In: Marschner's Mineral Nutrition of Higher Plants. P. Marschner (Ed.), Academic Press, UK: 191-248.

Burgess P.J., Carr M.K.V., 1996. Responses of young tea (Camellia sinensis) clones to drought and temperature. I. Yield and yield distribution. Exp. Agric. 32: 357-372.

CARr M.K.V., 1972. The climatic requirements of the tea plant: A review. Exp. Agric. 8: 1-14.

CARr M.K.V., 1977. Responses of seedling tea bushes and their clones to water stress. Exp. Agric. 13: 317324.

CARR M.K.V., 1985. Some effects of shelter on the yield and water use of tea. In: Effects of Shelter on the Physiology of Plants and Animals. Progress in Biometeorology, Vol. 2. J. Grace (Ed.), Swets \& Zeitlinger B.V., Lisse, Netherlands: 127-144.

Carr M.K.V., Stephens W., 1992. Climate, weather and the yield of tea. In: Tea: Cultivation to Consumption.
K.C. Willson and M.N. Clifford (Eds), Chapman \& Hall, London, UK: 87-135.

CARr M.K.V., 2000. Shoot growth plus plucking equals profit. TRIT Occasional Publication No. 1. Tea Research Institute of Tanzania, Dar es Salaam. Available online at http://www.trit.or.tz/publications. php; cited on 10 Oct 2017.

Carr H.P., Lombi E., Kupper H., Mcgrath S.P., Wong M.H., 2003. Accumulation and distribution of aluminium and other elements in tea (Camellia sinensis) leaves. Agronomie 23: 705-710.

CARR M.K., 2010. The role of water in the growth of the tea (Camellia sinensis) crop: a synthesis of research in Eastern Africa. 1. Water relations. Exp. Agric. 46: 327-349.

Charles-Edwards $\quad$ D.A., 1982. Physiological Determinants of Crop Growth. Academic Press, London, UK.

Cheruiyot E.K., Mumera L.M., NG'Etich W.K., Hassanali A., Wachira F.N., 2007. Polyphenols as potential indicators for drought tolerance in tea (Camellia sinensis L.). Biosci. Biotechnol. Biochem. 71: 2190-2197.

Cheruiyot E.K., Mumera L.M., NG'etich W.K., Hassanali A., Wachira F.N., 2008. Threshold soil water content for growth of tea [Camellia sinensis (L.) O. Kuntze]. Tea 29: 29-38.

Cheruiyot E.K., Mumera L.M., NG'Etich W.K., Hassanali A., Wachira F.N., 2009. High fertilizer rates increase susceptibility of tea to water stress. J. Plant Nutr. 33: 115-129.

Chin F.S., Ho T.Y., Chong K.P., Jalloh M.B., Wong N.K., 2010. Organic versus conventional farming of tea plantation. Borneo Sci. 26: 19-26.

Darnhofer I., Lindenthal T., Bartel-KratochVIL R., Zollitsch W., 2010. Conventionalisation of organic farming practices: from structural criteria towards an assessment based on organic principles. A review. Agron. Sustain. Dev. 30: 67-81.

Das A., Das S., Mondal T.K., 2012. Identification of differentially expressed gene profiles in young roots of tea (Camellia sinensis (L.) O. Kuntze) subjected to drought stress using suppression subtractive hybridization. Plant Mol. Biol. 30: 1088-1101.

de Costa W.J., Mohotti A., Wijeratne M., 2007. Ecophysiology of tea. Braz. J. Plant Physiol. 19: 299332.

DE SiLVA L.D.S.M., 2007. The effects of soil amendments on selected properties of tea soils and tea plants (Camellia sinensis L.) in Australia and Sri-Lanka. Ph.D. dissertation, James Cook University, Australia.

du Toit R., Volsteedt Y., Apostolides Z., 2001. Comparison of the antioxidant content of fruits, vegetables and teas measured as vitamin C equivalents. Toxicology 166: 63-69.

Dufresne C.J., FARnworth E.R.A., 2001. Review of latest research findings on the health promotion properties of tea. J. Nutr. Biochem. 12: 404-421. 
Duncan J.M., Saikia S.D., Gupta N., Biggs E.M., 2016. Observing climate impacts on tea yield in Assam, India. Appl. Geogr. 77: 64-71.

FAO (Food And Agriculture Organization Of The United NATIONS), 2014. FAOSTAT: Available online at http://www.fao.org/faostat/en/\#data/QC; cited on 10 Oct 2017.

FAO (Food And Agriculture Organization Of The United NATIONS), 2015. World tea production and trade: Current and future development. Available online at http://www.fao.org/3/a-i4480e.pdf; cited on 10 Oct 2017.

FAO (Food And Agriculture Organization Of The United Nations), 2016. Report of the Working Group on Climate Change of the FAO Intergovernmental Group on Tea. FAO, Rome, Italy.

Fordham R., Palmer-Jones R.W., 1977. Simulation of intraseasonal yield fluctuations of tea in Malawi. Exp. Agric. 13: 33-42.

Gamage A.J., Wijeratne M.A., De Costa W.A.J.M., 2007. Role of shade trees in tea: A low-country perspective. Proc. $215^{\text {th }}$ Meeting of the Experiments and Extension Forum. Tea Research Institute of Sri Lanka, Talawakelle, Sri Lanka.

Gee G.W., Sandanam S., Kulasegaram S., ANANDACOOMARASWAMY A., 1982. Effect of shade on leaf water diffusion resistance in clonal tea (Camellia sinensis). Tea Q. 51: 12-20.

Ghanati F., Morita A., YoKota H., 2005. Effects of aluminum on the growth of tea plant and activation of antioxidant system. Plant Soil 276: 133-141.

Hajiboland R., Bastani S., Rad S.B., 2011. Effect of light intensity on photosynthesis and antioxidant defense in boron deficient tea plants. Acta Biol. Szeged. 55: 265-272.

Hajiboland R., Bastani S., 2012. Tolerance to water stress in boron-deficient tea (Camellia sinensis) plants. Folia Hort. 24: 41-51.

Hajiboland R., Bahrami-Rad S., Barceló J., Poschenrieder C., 2013a. Mechanisms of aluminum-induced growth stimulation in tea (Camellia sinensis). J. Plant Nutr. Soil Sci. 176: 616625.

Hajiboland R., Bahrami-Rad S., Bastani S., Tolrà R., Poschenrieder C., 2013b. Boron re-translocation in tea (Camellia sinensis (L.) O. Kuntze) plants. Acta Physiol. Plant. 35: 2373-2381.

Hajiboland R., Barceló J., Poschenrieder C., Tolrà R., 2013c. Amelioration of iron toxicity: a mechanism for aluminum-induced growth stimulation in tea plants. J. Inorg. Biochem. 128: 183-187.

Hajiboland R., 2014. Reactive oxygen species and photosynthesis. In: Oxidative Damage to Plants, Antioxidant Networks and Signaling. P. Ahmad (Ed.), Springer, New York, USA: 1-63.

Hajiboland R., Bahrami-Rad S., Bastani S., 2014. Aluminum alleviates boron-deficiency induced growth impairment in tea plants. Biol. Plant. 58: 717724.

Hajiboland R., Salehi S.Y., 2014. Remobilization of phosphorus in tea plants. J. Plant Nutr. 37: 1522-1533.

Hajiboland R., Bastani S., Bahrami-Rad S., Poschenrieder C., 2015. Interactions between aluminum and boron in tea (Camellia sinensis) plants. Acta Physiol. Plant. 37: 1-13.

Hamid F.S., 2006. Yield and quality of tea under varying conditions of soil and nitrogen availability. Ph.D. dissertation, Quaid-i-Azam University Islamabad, Pakistan.

Han W., Kemmitt S.J., Brookes P.C., 2007. Soil microbial biomass and activity in Chinese tea gardens of varying stand age and productivity. Soil Biol. Biochem. 39: 1468-1478.

Hara Y., 2001. Antiviral action of tea polyphenols. In: Green Tea. Y. Hara (Ed.), Marcel Drekker, Inc., New York, USA.

Harbowy M.E., Balentine D.A., 1997. Tea chemistry. Crit. Rev. Plant Sci. 16: 415-480.

Hawkesford M., Horst W., Kichey T., Lambers H., Schjoerring J., Skrumsager Møller I., White P., 2012. Functions of macronutrients. In: Marschner's Mineral Mutrition of Higher Plants. P. Marschner (Ed.), Academic Press, UK: 135-189.

Hazarika L.K., Bhuyan M., Hazarika B.N., 2009. Insect pests of tea and their management. Ann. Rev. Entomol. 54: 267-284.

Hirel B., Tétu T., Lea P.J., Dubois F., 2011. Improving nitrogen use efficiency in crops for sustainable agriculture. Sustainability 3: 1452-1485.

Hirono Y., NonaKa K., 2012. Nitrous oxide emissions from green tea fields in Japan: contribution of emissions from soil between rows and soil under the canopy of tea plants. Soil Sci. Plant Nutr. 58: $384-$ 392.

Hirono Y., NonaKa K., 2014. Effects of application of lime nitrogen and dicyandiamide on nitrous oxide emissions from green tea fields. Soil Sci. Plant Nutr. 60: 276-285.

Hirono Y., Watanabe I., Nonaka K., 2009. Trends in water quality around an intensive tea-growing area in Shizuoka, Japan. Soil Sci. Plant Nutr. 55: 783-792.

Ho C.T., Lin J.K., Shahidi F., 2009. Tea and Tea Products: Chemistry and Health-Promoting Properties. CRC press, Taylor \& Francis group, Boca Raton, FL, USA.

IFOAM (INTERNATIONAL FEDERATION OF ORganic Agriculture Movements), 2016. Calls for Tea Industry to Safeguard Consumers' Right to Safe Tea. Available online at http://www.ifoam.bio/ en/news/2014/08/19/ifoam-calls-tea-industrysafeguard-consumers-right-safe-tea; cited on $10 \mathrm{Oct}$ 2017.

IoANnides C., Yoxall V., 2003. Antimutagenic activity of tea: role of polyphenols. Curr. Opin. Clin. Nutr. Metab. Care 6: 649-656. 
JAetzold R., Schmidt H., 1983. Farm Management Handbook of Kenya. Vol. II/B Central Kenya. Ministry of Agriculture, Kenya in Cooperation with German Agricultural Team (GAT) of German Agency of Technical Cooperation (GTZ).

Jagadeeswaran R., Murugappan V., Govindaswamy M., 2005. Effect of slow release NPK fertilizer sources on the nutrient use efficiency in turmeric (Curcuma longa L.). World J. Agric. Sci. 1: 65-69.

JESSY M.D., 2010. Potassium management in plantation crops with special reference to tea, coffee and rubber. Karnataka J. Agric. Sci. 24: 67-74.

KaraK T., Bhagat R.M., 2010. Trace elements in tea leaves, made tea and tea infusion: A review. Food Res. Int. 43: 2234-2252.

Karki L., Schleenbecker R., Hamm U., 2011. Factors influencing a conversion to organic farming in Nepalese tea farms. J. Agr. Rural Dev. Trop. 112: 113-123.

Karori S.M., Wachira F.N., NGure R.M., Mireji P.O., 2014. Polyphenolic composition and antioxidant activity of Kenyan tea cultivars. J. Pharmacogn. Phytochem. 3: 105-116.

Karunaratne P.M.A.S., Mohotti A.J., Nissanka S.P., GunAsinghe W.A.D.S.K., 2003. Effect of shade in minimizing photoinhibition of photosynthesis of high grown tea (Camellia sinensis (L.) O. Kuntze). Trop. Agric. Res. 15: 133-143.

Kavanagh D., Renehan J., 1997. Fluoride in tea- its dental significance: a review. J. Ir. Dent. Assoc. 44: 100-105.

Konishi S., Miyamoto S., TaKi T., 1985. Stimulatory effects of aluminum on tea plants grown under low and high phosphorus supply. Soil Sci. Plant Nutr. 31: 361-368.

Kumar P.V.S., Basheer S., Ravi R., Thakur M.S., 2011. Comparative assessment of tea quality by various analytical and sensory methods with emphasis on tea polyphenols. J. Food Sci. Technol. 48: 440-446.

Kumar R., Singh A.K., Bisen J.S., Choubey M., Singh M., BERA B., 2014. Influence of foliar application of micronutrients on physiological characteristics and yield of Darjeeling tea (Camellia sinensis L). Proc. $3^{\text {rd }}$ Int. Conf. on Agriculture and Horticulture, 2729 October, Hyderabad International Convention Centre, India: 64

Kutama A.S., Abdullahi M.A., Umar S., Binta U.B., Ahmad M.K., 2013. Organic farming in Nigeria: problems and future prospects. J. Agric. Sci. 2: 256262.

Lehmann-Danzinger H., 2000. Diseases and pests of tea: Overview and possibilities of integrated pest and disease management. J. Agric. Trop. Subtrop. 101: 13-38.

Maritim T., Kamunya S., Mwendia Ch., Mireji P., Muoki R., Wamalwa M., Francesca S., Schaack S., Kyalo M., Wachira F., 2016. Transcriptomebased identification of water-deficit stress responsive genes in the tea plant, Camellia sinensis. J. Plant Biotechnol. 43: 302-310.

Matthews R.B., Stephens W., 1998a. CUPPA-TEA: A simulation model describing seasonal yield variation and potential production of tea. 2. Biomass production and water use. Exp. Agric. 34: 369-389.

Matthews R.B., Stephens W., 1998b. The role of photoperiod in determining seasonal yield variation in tea. Exp. Agric. 34: 323-340.

Монотті A.J., 1998. Effect of irradiance and N nutrition on photosynthesis of tea (Camellia sinensis (L.) O. Kuntze) in comparison with sunflower (Helianthus annus L.). Ph.D. dissertation, University of Reading, UK.

Монотті A.J., 2004. Shade in tea: Is it beneficial? Sri Lanka J. Tea Sci. 69: 27-39.

Mohotti A.J., Dennett M.D., Lawlor D.W., 2000. Electrontransport as a limitation to photosynthesis of tea (Camellia sinensis (L.) O. Kuntze): a comparison with sunflower (Helianthus annus L.) with special reference to irradiance. Trop. Agric. Res. 12: 1-10.

Монотті A.J., LAwLOR D.W., 2002. Diurnal variation of photosynthesis and photoinhibition in tea: effects of irradiance and nitrogen supply during growth in the field. J. Exp. Bot. 53: 313-322.

MoKAYA, B.N., 2016. Effect of varying rates of organic and inorganic fertilizers on growth, yield and nutrient use efficiency of clonal tea (Camellia sinensis [L.] O. Kuntze). M.Sc. thesis, University of Nairobi, Kenya: 78.

Morré D.J., Morré D.M., Sun H., Cooper R., Chang J., JANLE E.M., 2003. Tea catechin synergies in inhibition of cancer cell proliferation and of a cancer specific cell surface oxidase (ECTO-NOX). Pharmacol. Toxicol. 92: 234-241.

Mukhtar H., Ahmad N., 1999. Green tea in chemoprevention of cancer. Toxicol. Sci. 52: 111-117.

Muoki R.C., Paul A., Kumar S., 2012. A shared response of thaumatin like protein, chitinase and late embryogenesis abundant protein to environmental stresses in tea (Camellia sinensis (L.) O. Kuntze). Funct. Integr. Genomics 12: 565-571.

NATH T.N., 2013. Status of macronutrients in some selected tea growing soils in Dibrugarh Sivasagar Districts of Assam, India. Int. J. Sci. Res. 2: 273-275.

Nelson S., 2006. Zinc deficiency in tea (Camellia Sinensis). Plant Disease. PD-34. Available online at https://www.ctahr.hawaii.edu/oc/freepubs/pdf/PD34.pdf; cited on 10 Oct 2017.

NeumanN G., Römheld V., 2012. Rhizosphere chemistry in relation to plant nutrition. In: Marschner's Mineral Mutrition of Higher Plants. P. Marschner (Ed.), Academic Press, UK: 3347-3368.

NG'ETICH W.K., 1999. Effects of different applied nitrogen rates on yield and plant survival during periods of water stress. Tea 20: 61-65. 
NiXON D.J., SANGa B.N.K., 1995. Dry weight and root distribution of unirrigated mature tea. Ngwazi Tea Res. Unit. Quart. Rep. 21: 18-23.

Nooloma C., 2012. Application of foliar sprays containing copper, zinc and boron to mature clonal tea (Camellia sinensis): effect on yield and quality. M.Sc. thesis, University of Pretoria, South Africa.

Ogunmoyela O.A., Obatolu C.R., Adetunji M.T., 1994. Effect of soil micronutrient status on the fermentation characteristics and organoleptic quality of Nigerian tea. Afr. Crop Sci. J. 2: 87-92.

Oh K., Kato T., Zhong-Pei L., Fa-Yun L., 2006. Environmental problems from tea cultivation in Japan and a control measure using calcium. Pedosphere 16: 770-777.

Okano K., Komaki S., Matsuo K., Hirose D., Tatsumi J., 1995. Analysis of canopy photosynthesis in mature tea (Camellia sinensis L.) bush at late autumn. Jpn. J. Crop Sci. 64: 310-316.

OthiENo C.O., 1982. Diurnal variations in soil temperature under tea plants. Exp. Agric. 18: 195202.

Owuor P.O., 1997. Fertilizer use in tea: The case of nitrogen. Tea 18: 132-143.

Owuor P.O., NG'Etich W.K., Obanda M., 2000. Quality response of clonal black tea to nitrogen fertilizer, plucking interval and plucking standard. J. Sci. Food Agric. 80: 438-446.

Owuor P.O., Obanda M., Nyirenda H.E., Mphangwe N.I.K., Wright L.P., Apostolides Z., 2006. The relationship between some chemical parameters and sensory evaluations for plain black tea (Camellia sinensis) produced in Kenya and comparison with similar teas from Malawi and South Africa. Food Chem. 97: 644-653.

Patel S.H., 2005. Camellia sinensis: historical perspectives and future prospects. J. Agromedicine 10: 57-64.

Ping X., Liyun Y., Moucheng L., Fei P., 2014. Soil characteristics and nutrients in different tea garden types in Fujian Province, China. J. Resour. Ecol. 5: 356-363.

Poorter H., Navas M.L., 2003. Plant growth and competition at elevated $\mathrm{CO}_{2}$ : on winners, losers and functional groups. New Phytol. 157: 175-198.

Poschenrieder C., Gunsé B., Corrales I., Barceló J.A., 2008. A glance into aluminum toxicity and resistance in plants. Sci. Total Environ. 400: 356368.

Poschenrieder C., Tolra R., Hajiboland R., Arroyave C., Barceló J., 2015. Mechanisms of hyper-resistance and hyper-tolerance to aluminum in plants. In: Aluminum Stress Adaptation in Plants. S.K. Panda and F. Baluška (Eds), Springer, Switzerland: 81-98.

Qiu SL., Wang L.M., Huang D.F., Lin X.J., 2014. Effects of fertilization regimes on tea yields, soil fertility, and soil microbial diversity. Chil. J. Agr. Res. 74: 333-339.

Rattan P.S., 1992. Pest and disease control in Africa. In: Tea: Cultivation to Consumption. K.C. Willson and M.N. Clifford (Eds), Chapman \& Hall, London, UK: 331-352.

Rengel Z., 2015. Availability of Mn, Zn and Fe in the rhizosphere. J. Soil Sci. Plant Nutr. 15: 397-409.

RoBERTS T.L., 2008. Improving nutrient use efficiency. Turk. J. Agric. 32: 177-182.

RUAN J., 2005. Quality-related constituents in tea (Camellia sinensis (L.) O. Kuntze) as affected by the form and concentration of nitrogen and the supply of chloride. Ph.D. dissertation, Christian-Albrechts Universität Kiel, Germany.

Ruan J., Gerendás J., Härdter R., Sattelmacher B., 2007. Effect of root zone $\mathrm{pH}$ and form and concentration of nitrogen on accumulation of quality-related components in green tea. J. Sci. Food Agric. 87: 1505-1516.

Ruan J., Zhang F., Wong MH., 2000. Effect of nitrogen form and phosphorus source on the growth, nutrient uptake and rhizosphere soil property of Camellia sinensis L. Plant Soil 223: 65-73.

RUAN J.Y., WU X., 2004. Nutrient input and evaluation of fertilization efficiency in typical tea areas of China. In: Nutrient Management in China. Part I. Nutrient Balances and Nutrient Cycling in Agro-ecosystems. R. Härdter, J. Xie, J. Zhou and Q. Fan (Eds), International Potash Institute, Basel, Switzerland: 367-375.

Ruan L., Wei K., Wang L., Cheng H., Zhang F., Wu L., Bai P., Zhang Ch., 2016. Characteristics of $\mathrm{NH}_{4}^{+}$and $\mathrm{NO}_{3}^{-}$fluxes in tea (Camellia sinensis) roots measured by scanning ion-selective electrode technique. Sci. Rep. 6: 38370.

Ruter, J.M., 2002. Nursery production of tea oil camellia under different light levels. In: Trends in New Crops, New Uses. J. Janick and A. Whipkey (Eds), ASHS Press, Alexandria: 222-224.

SAlehi S.Y., Hajiboland R., 2008. A high internal phosphorus use efficiency in tea (Camellia sinensis L.) plants. Asian J. Plant Sci. 7: 30-36.

Sandanam S., Gee G.W., Mapa R.B., 1981. Leaf water diffusion resistance in clonal tea (Camellia sinensis L.): Effects of water stress, leaf age and clones. Ann. Bot. 47: 339-349.

Sanderson G.W., Sivapalan K., 1966a. Effect of leaf age on photosynthetic assimilation of carbon dioxide in tea plants. Tea Q. 37: 11-26.

Sanderson G.W., Sivapalan K. 1966b. Translocation of photosynthetically assimilated carbon in tea plants. Tea Q. 37: 140-153.

Sharma P., Kumar A., 2005. Differential displaymediated identification of three drought-responsive expressed sequence tags in tea (Camellia sinensis (L.) O. Kuntze). J. Biosci. 30: 231-235. 
SivaPAlAN P., 1993. Shade and green manure trees in tea-A holistic appraisal. Sri Lank. J. Tea Sci. 62: 4146.

Smith B.G., Burgess P.J., CARr M.K.V., 1994. Effects of clone and irrigation on the stomatal conductance and photosynthetic rate of tea (Camellia sinensis). Exp. Agric. 30: 1-16.

Smith B.G., Stephens W., Burgess P.J., Carr M.K.V., 1993. Effects of light, temperature, irrigation and fertilizer on photosynthetic rate in tea (Camellia sinensis). Exp. Agric. 29: 291-306.

SQUiRE G.R., 1979. Weather, physiology and seasonality of tea (Camellia sinensis) yields in Malawi. Exp. Agric. 15: 321-330.

SQuire G.R., 1990. The Physiology of Tropical Crop Production. CAB International, Wallingford, UK.

Squire G.R., Callander B.A., 1981. Tea plantations. In: Water Deficits and Plant Growth. Vol. VI. T.T. Kozlowski (Ed.), Academic Press, New York, USA: 471-510.

Squire G.R., Obaga S.M.O., Othieno C.O., 1993. Altitude, temperature and shoot production of tea in the Kenyan Highlands. Exp. Agric. 29: 107-120.

Stephens W., Carr M.K.V., 1990. Seasonal and clonal differences in shoot extension rates and numbers in tea (Camellia sinensis). Exp. Agric. 26: 83-98.

Stephens W., Carr M.K.V., 1991. Responses of tea (Camellia sinensis) to irrigation and fertilizer. II. Water use. Exp. Agric. 27: 193-210.

Stephens W., Carr M.K.V., 1993. Responses of tea (Camellia sinensis) to irrigation and fertilizer. III. Shoot extension and development. Exp. Agric. 29: 323-339.

Stephens W., Carr M.K.V., 1994. Responses of tea (Camellia sinensis) to irrigation and fertilizer. IV. Shoot population density, size and mass. Exp. Agric. 30: 189-205.

Sultana J., Siddique M.N.A., Kamaruzzaman M., Halim M.A., 2014. Conventional to ecological: Tea plantation soil management in Panchagarh District of Bangladesh. J. Sci. Technol. Environ. Inform. 1: 27-35.

Tabu I.M., KeKana V.M., Kamau D.M., 2015. Effects of varying ratios and rates of enriched cattle manure on leaf nitrogen content, yield and quality of tea (Camellia sinensis). J. Agric. Sci. 7: 175-181.

TANaka J., TAniguchi F., 2006. Estimation of the genome size of tea (Camellia sinensis), Camellia (C. japonica), and their interspecific hybrids by flow cytometry. J. Remote Sens. Soc. Jpn. 101: 1-7.

Tanaka T., Ii H., Hirata T., Nishikawa M., Umehara K., OGawA Y., 2002. Groundwater metal and nitrogen contaminations caused by nitrogen fertilizer in tea plantation catchment, the center of Shizuoka, Japan. J. Hydrosci. Hydraul. Eng. 20: 37-47.

TAnton T.W., 1979. Some factors limiting yields of tea (Camellia sinensis). Exp. Agric. 15: 187-192.
TANTON T.W., 1982. Environmental factors affecting the yield of tea (Camellia sinensis). II. Effects of soil temperature, day length and dry air. Exp. Agric. 18: 53-63.

TAnton T.W., 1992. Tea crop physiology. In: Tea: Cultivation to Consumption. K.C. Willson and M.N. Clifford (Eds), Chapman \& Hall, London, UK: 173199.

Thenmozhi K., Manian S., Paulsamy S., 2012. Influence of long term nitrogen and potassium fertilization on the biochemistry of tea soil. J. Res. Agric. 1: 124-135.

Tomljenovic L., 2011. Aluminum and Alzheimer's disease: after a century of controversy, is there a plausible link? J. Alzheimers Dis. 23: 567-598.

TRFK (Tea Research Foundation Of Kenya), 2002. Tea Growers' Handbook. $5^{\text {th }}$ ed. Kijabe Printing Press, Kijabe, Kenya.

TRFK (Tea Research Foundation Of Kenya), 2012. Tea Cultivation Manual for Good Agricultural Practices. $1^{\text {st }}$ ed. Nairobi, Kenya.

Vadez V., Kholova J., Medina S., Kakkera A., Anderberg H., 2014. Transpiration efficiency: new insights into an old story. J. Exp. Bot. 65: 6141-6153.

Venkatesan S., Ganapathy M.N., 2004. Nitrate reductase activity in tea as influenced by various levels of nitrogen and potassium fertilizers. Commun. Soil Sci. Plant Anal. 35: 1283-1291.

Venkatesan S., Murugesan S., Ganapathy M.N., Verma D.P., 2004. Long-term impact of nitrogen and potassium fertilizers on yield, soil nutrients and biochemical parameters of tea. J. Sci. Food Agric. 84: 1939-1944.

WaArts Y., Ge L., Ton G., Jansen D., 2012. Sustainable Tea Production in Kenya: Impact Assessment of Rainforest Alliance and Farmers Field Schools Trainings. LEI, Wageningen, Netherlands.

Wang H., Xu R.K., Wang N., Li X.H., 2010. Soil acidification of alfisols as influenced by tea cultivation in Eastern China. Pedosphere 20: 799806.

Wanyoko J.K., Kamau D., Wachira F., Koech R., 2011. Organic tea in Kenya. TRFK Quar. Bull. 16: 12-15.

Wei C.L., Jiang C.J., Jiang C.J., TaO H.Z., Hu Y.H., 2004. Analysis of the xanthophyll cycle component in fresh leaves of tea plant by high performance liquid chromatography and its photo-protection. J. Tea Sci. 24: 60-64.

Weinreb O., Mandel S., Amit T., Youdim M.B., 2004. Neurological mechanisms of green tea polyphenols in Alzheimer's and Parkinson's diseases. J. Nutr. Biochem. 15: 506-516.

WiJeratne M.A., 1994. Effect of climatic factors on the growth of tea (Camellia sinensis L.) in the low country wet zone of Sri Lanka. Ph.D. dissertation, University of London, UK. 
WiJeratne M.A., 1996. Vulnerability of Sri Lanka tea production to global climate change. Water Air Soil Poll. 92: 87-94.

Wijeratne M.A., Fordham R., 1996. Effects of environmental factors on growth and yield of tea (Camellia sinensis L.) in the low-country wet zone of Sri Lanka. Sri Lanka J. Tea Sci. 64: 21-34.

Wijeratne M.A., Anandacoomaraswamy A., Amarathunga M.K.S.L.D., Ratnasiri J., Basnayake B.R.S.B., Kalra N., 2007a. Assessment of impact of climate change on productivity of tea (Camellia sinensis L.) plantations in Sri Lanka. J. Natn. Sci. Foundation Sri Lanka 35: 119-126.

Wijeratne M.A., Ratnasiri J., Premathunga E.W.T.P., 2007b. Effect of $\mathrm{CO}_{2}$ fertilization on growth and yield of mature tea in the low country wet zone of Sri Lanka. J. Plant. Crops 35: 56-58.

Wijeratne M.A., Chandrapala L., 2013. Analysis of rainfall and temperature in tea growing Agroecological Regions and assessment of vulnerability of tea plantations in Sri Lanka to climate change. Sri Lanka J. Tea Sci. 78: 42-59.
Willer H., Yussefi M., Sorensen N., 2008. The World of Organic Agriculture: Statistics and Emerging Trends. IFOAM, Switzerland.

Williges U., 2004. Status of organic agriculture in Sri Lanka with special emphasis on tea (Camellia sinensis (L.) O. Kuntze) production systems. Ph.D. dissertation, Justus-Liebig-University of Giessen, Germany.

Xu Q., Wang Y., Ding Z., Fan K., Ma D., Zhang Y., YIN Q., 2017. Aluminum induced physiological and proteomic responses in tea (Camellia sinensis) roots and leaves. Plant Physiol. Biochem. 115: 141-151.

Yashin A.Y., Nemzer B.V., Combet-Aspray E., YASHIN Y.I., 2015. Determination of the chemical composition of tea by chromatographic methods: a review. J. Food Res. 4: 56-87.

ZHEN Y.S., 2002. Tea: Bioactivity and Therapeutic Potential. Taylor \& Francis, New York, USA.

Ziola-Frankowska A., Frankowski M., Novotny K., KANICKY V., 2014. Comparison of the level of boron concentrations in black teas with fruit teas available on the polish market. Sci. World J. 898425: 1-8.

Received April 24, 2017; accepted September 23, 2017 